\title{
THE MEANING OF "GENERAL LAWS": THE EXTENT OF CONGRESS'S POWER UNDER THE FULL FAITH AND CREDIT CLAUSE AND THE CONSTITUTIONALITY OF THE DEFENSE OF MARRIAGE ACT
}

\author{
JULIE L. B. JOHNSON ${ }^{\dagger}$
}

\section{INTRODUCTION}

On September 21, 1996, President Clinton signed the Defense of Marriage Act ("DOMA" or "Act") into law." The Act is a direct response to a recent decision by the Supreme Court of Hawaii, Baehr v. Lewin, ${ }^{2}$ that ultimately may lead to the recognition of same-sex

† A.B. 1992, Duke University; J.D. Candidate 1998, University of Pennsylvania. I would like to thank Professor Seth Kreimer of the University of Pennsylvania for providing me with the idea for this Comment and for his generous assistance. I have also benefited from conversations with William Eskridge, Jr., Professor of Law at Georgetown University Law Center, and Andrew Chirls, Partner at Wolf, Block, Schorr, \& Solis-Cohen, in Philadelphia. Lastly, I would like to thank the members of the Law Review for their unpaid and largely unrewarded efforts. Any errors remaining, however, should be attributed to them anyway.

' Pub. L. No. 104-199, 110 Stat. 2419 (1996) (codified at 28 U.S.C.A. § 1738C (West Supp. 1997) and 1 U.S.C.A. $\$ 7$ (West 1997)).

${ }^{2} 852$ P.2d 44 (Haw. 1993). The plaintiffs, three homosexual couples, challenged their denial of marriage licenses on several grounds. See id. at 48-50. The court, holding that fundamental rights under the Hawaii Constitution are coextensive with fundamental rights under the Constitution of the United States, first held that couples do not possess a fundamental right to same-sex marriage, based on privacy or other grounds. See id. at 57. The court, however, did find that the state statute granting marriage licenses only to opposite-sex couples constituted sex-based discrimination, see $i d$. at 60 , thus implicating the equal protection guarantees of the Hawaii Constitution, as modified by an equal rights amendment, see id. at 63-67. The court went on to conclude that, for purposes of equal protection analysis under the Hawaii Constitution, sex was a "suspect category" subject to strict scrutiny. See id. at 67. The court thus declined to decide whether sexual orientation was a suspect category, finding that the sexual orientation of the plaintiffs was irrelevant to their decision. See id. at $58 \mathrm{n} .17$. The Hawaii Supreme Court remanded the case to the lower court to determine whether the state could prove that the statute denying marriage licenses to same-sex couples furthered a compelling state interest and was narrowly drawn to avoid unnecessary constitutional deprivations. See id. at 68.

On remand, the Hawaii Circuit Court held that the state had failed to meet its burden. See Baehr v. Miike, CIV. No. 91-1394, 1996 WL 694235, at *21 (Haw. Cir. Ct. Dec. 3, 1996). To prevent potential chaos, the court issued an order suspending the 
marriages ${ }^{3}$ in Hawaii. ${ }^{4}$ The DOMA contains two substantive provisions. One provision defines "marriage" and "spouse" for federal purposes as requiring two persons of the opposite sex. ${ }^{5}$ The other substantive provision, section 2 of the Act, provides that states do not

issuance of licenses to same-sex couples until a final decision has been reached by the Hawaii Supreme Court. See Ellen Goodman, Delayed Trips to Altar May Gain More for Gays, ARIZ. REPUBLIC, Dec. 12, 1996, at B7, available in 1996 WL 7761488.

"Throughout this Comment, the terms "same-sex" and "homosexual" are used interchangeably. It bears emphasis, however, that the terms are not synonymous. For example, a homosexual marriage could also be defined as a marriage between a homosexual man and a lesbian woman. Likewise, a same-sex marriage could be a marriage in which one or both of the parties is heterosexual. This distinction was pointed out in Baehr v. Lewin, 852 P.2d at $51 \mathrm{n} .11$. As a practical matter, the majority of same-sex couples seeking the right to marry probably would be homosexual couples. There are other possibilities, however, such as two elderly individuals who choose to live together for financial reasons and companionship, who comprise a family of sorts, and who would appreciate the numerous benefits of marriage.

1 See H.R. REP. NO. 104-664, at 2 (1996) (noting the Act's specific purpose of responding to Baehr $v$. Lewin). The aftermath of Baehr $v$. Lewin has been extraordinary. Apart from provoking the passage of the DOMA, many states, including Hawaii, have reacted. The Hawaii state legislature passed legislation limiting marital rights to opposite-sex couples in an attempt to sway the court's decision on remand. See Hawaii's Marriage Laws Don't Sanction Same-Sex Marriages, 20 Fam. L. Rep. (BNA) 1448, at 1448 (Aug. 2, 1994) [hereinafter Hawaii's Marriage Laws]. This legislation, however, would have no force if the decision in Baehr v. Miike is upheld by the Hawaii Supreme Court. Thus, the state has called for the only remaining option: a constitutional convention, which has been scheduled for 1998 to discuss amending or repealing the equal rights amendment to the Hawaii Constitution to strip the Baehr decision of its constitutional support. See Hawaii Seeks Law to Block Gay Marriage, N.Y. TIMES, Apr. 18, 1997, at A15 [hereinafter Hawaii Seeks Law].

${ }^{5}$ See Defense of Marriage Act $\$ 3$. The Supreme Court has often referred to the regulation of marriage as being under the exclusive control of the states. See, e.g., Sherrer v. Sherrer, 334 U.S. 343, 354 (1948) ("[U]nder the Constitution the regulation and control of marital and family relationships are reserved to the States."); Williams v. North Carolina, 325 U.S. 226, 232-33 (1945) (stating the need for "due regard for [a] most important aspect of our federalism whereby 'the domestic relations of husband and wife ... were matters reserved to the States,' and do not belong to the United States" (omission in original) (quoting Ohio ex rel. Popovici v. Agler, 280 U.S. 379, 384 (1930))). The federal government, however, may not be constitutionally bound by state definitions of terms such as "marriage" and "spouse." For example, Congress has defined "spouse" for purposes of Social Security benefits. See 42 U.S.C. § 416(a), (b), (f) (1994). In addition, a federal court has suggested, in dictum, that a same-sex marriage, valid under state law, "might still be insufficient to confer spouse status for purposes of federal immigration law." Adams v. Howerton, 673 F.2d 1036, 1039 (9th Cir. 1982). However, as the court pointed out, Congress may impose burdens on aliens that would be unconstitutional if imposed on citizens. See id. at 1042. This Comment does not address section 3 of the Act or the constitutional question of Congress's authority to define these terms contrary to state definitions. 
have to recognize a same-sex marriage performed and valid in another state. ${ }^{6}$ The latter provision is the focus of this Comment.

In enacting section 2 of the DOMA, Congress purported to act pursuant to its power under the Full Faith and Credit Clause of the Constitution. ${ }^{7}$ The Full Faith and Credit Clause allows Congress to prescribe "by general Laws" the effect that one state's "public Acts, Records, and judicial Proceedings" will have in every other state. Prior to the Act, Congress had exercised power under this Clause on only three occasions.' Each time it acted either to clarify or to extend the application of the Full Faith and Credit Clause; for example, by mandating full faith and credit for custody decrees to ensure cooperation among the states. ${ }^{10}$ The DOMA is thus the first attempt by Congress to limit application of the Full Faith and Credit Clause.

This congressional withdrawal of full faith and credit, on its own, raises constitutional concerns. Some commentators believe that the Act is unconstitutional because the limiting of full faith and credit contravenes the unifying principles of the Full Faith and Credit Clause." However, there is no direct support for this proposition in

${ }^{6}$ See Defense of Marriage Act $\S 2$.

${ }^{7}$ U.S. CONST. art. IV, $\$ 1$.

${ }^{8}$ Id.

${ }^{9}$ See infra note 56.

${ }^{10}$ See 28 U.S.C. § 1738A (1994).

"Professor Laurence Tribe, in a letter submitted to the Senate and incorporated into the record, argued that "[i]t would do violence not only to the letter but also to the spirit of the Full Faith and Credit Clause to construe it as a fount of affirmative authority for Congress ... to set asunder the States that this clause brought together." 142 CONG. REC. S5933 (daily ed. June 6, 1996) (letter of Professor Laurence H. Tribe). There is at least indirect support for this position in that the Supreme Court has always interpreted the purpose of the Full Faith and Credit Clause as a means to unify the various states into a cohesive whole. See, e.g., Hughes v. Fetter, 341 U.S. 609, 612 \& n.9 (1951) (describing the "strong unifying principle embodied in the Full Faith and Credit Clause"); Estin v. Estin, 334 U.S. 541, 546 (1948) ("[The Full Faith and Credit Clause] ordered submission by one State even to hostile policies reflected in the judgment of another State, because the practical operation of the federal system, which the Constitution designed, demanded it."); Magnolia Petroleum Co. v. Hunt, 320 U.S. 430, 439 (1943) ("The full faith and credit clause ... became a nationally unifying force. It altered the status of the several states as independent foreign sovereignties ... by making each an integral part of a single nation, in which rights judicially established in any part are given nation-wide application.").

The Court, however, has never confronted the specific question whether Congress can withhold application of full faith and credit. There is no reason, in theory, why Congress could not exempt broad classes of records, acts, or proceedings from the demands of full faith and credit. Cf. Yarborough v. Yarborough, 290 U.S. 202, 215 n.2 (1933) (Stone, J., dissenting) (" $[\mathrm{T}]$ he mandatory force of the full faith and credit 
either the text or the legislative history of the Clause or its implementing act. ${ }^{12}$ It is therefore uncertain whether the Supreme Court would overturn the statute on this ground.

A more suspect facet of this legislation is its selective impact on the recognition of extraterritorial acts, records, and judicial proceedings. ${ }^{13}$ With regard to acts and records, the Act will disrupt the general rule that a marriage valid in one state will be recognized in every other state. ${ }^{14}$ The disruption with regard to judicial proceedings will be even greater. As the full faith and credit doctrine has evolved over the last two centuries, it has been applied with the most rigor to state judgments. ${ }^{15}$ The DOMA, however, declares that even a state judgment validating a same-sex marriage need not be given full faith and credit in another state's court. ${ }^{16}$

Thus, the first reason that this reversal in the full faith and credit doctrine is problematic is that it singles out a very narrow class of acts, records, and judgments to be denied full faith and credit. Congress's power to legislate regarding the effect of acts, records, and proceedings is limited to "general Laws." Although there has been almost no discussion of this aspect of the Clause, the language suggests that Congress may make only general rules regarding extraterritorial recognition, and may not target a specific segment of acts, records, or judgments.

Perhaps even more disturbing is the portent of the Act if allowed to stand: the asserted ability of Congress to restrict the scope of the Full Faith and Credit Clause through legislation. If Congress is per-

clause as defined by this Court may be, in some degree not yet fully defined, expanded or contracted by Congress.").

${ }^{12}$ For a discussion of Congress's power to legislate under the Full Faith and Credit Clause, see infra Part V.A.

${ }^{13}$ At the least, the unprecedented nature of this legislation should arouse the Court's suspicion. Cf. Romer v. Evans, 116 S. Ct. 1620, 1628 (1996) (asserting that "' [d] iscriminations of an unusual character especially suggest careful consideration to determine whether they are obnoxious to the [equal protection] provision.") (first alteration in original) (quoting Louisville Gas \& Elec. Co. v. Coleman, 277 U.S. 32, 3738 (1928)).

14 See discussion infra Part II.A. It is important to note that because the Supreme Court has not determined whether a marriage would be regarded as a "public act" or "record" within the meaning of the Full Faith and Credit Clause, states usually refer to comity concerns, rather than full faith and credit, when recognizing a marriage valid in another state. See H.R. REP. No. 104-664, at 38 (1996) (citing AlBERT A. EHRENZWEIG, A TREATISE ON THE CONFLICT OF LAWS $\$ 138$ (1961)).

${ }^{15}$ See infra notes $48-49$ and accompanying text.

${ }^{16}$ See Defense of Marriage Act § 2, 28 U.S.C.A. \$ 1738C (West Supp. 1997).

${ }^{17}$ U.S. Consr, art. IV, § 1. 
mitted to withdraw the mandate of full faith and credit from specific acts, records, or judgments, the status of each state as an independent sovereign within our federal system is vulnerable. Just as Hawaii may find that some of its marriages and judicial decrees may be disregarded by other states, as a matter of federal law, so too Kentucky may find that another state need not honor its commercial contracts, or Wyoming may discover that its wrongful death judgment will not always be enforced in every other state. ${ }^{18}$ In combination, the narrowness of the Act and its unprecedented limiting purpose should be sufficient grounds for the Supreme Court to declare the Act unconstitutional.

A full understanding of the legislation's potential unconstitutionality requires an examination of many substantive areas, including the history of the Full Faith and Credit Clause, its interpretation against a background of conflict-of-laws rules, and their combined application to the unique area of marriage.

Traditionally, states have recognized a marriage as valid if it would be valid in the state in which it was performed. ${ }^{19}$ However, states have sometimes refused to do so when such recognition would violate a strong public policy of the state. ${ }^{20}$ The ostensible purpose of the DOMA is to bolster the states' ability to deny recognition of extraterritorial same-sex marriages. ${ }^{21}$ The public policy exception already available to the states may appear to render section 2 of the DOMA superfluous. However, closer examination reveals that Congress purports to do far more than codify the existing public policy excep-

${ }^{18}$ Many congressional opponents of the DOMA accused its supporters of making a "power grab" from the states. See, e.g., 142 CONG. REC. S10,107 (daily ed. Sept. 10, 1996) (statement of Sen. Kerry). In addition, Professor Laurence Tribe suggested that passage of the DOMA would make possible increased congressional interference with the states, as an interpretation of the Full Faith and Credit Clause that validated the DOMA "would entail the conclusion that congress may constitutionally decree that no Hawaii marriage, no California divorce, no Kansas default judgment ... need[s] to be given any legal effect at all by any State that chooses to avail itself of a congressional license to ignore the Full Faith and Credit Clause." 142 CONG. REC. S5932 (daily ed. June 6, 1996) (letter of Professor Laurence H. Tribe). For a further discussion of this issue, see infra Part V.B.

${ }^{19}$ See discussion infra Part II.A.

${ }^{20}$ See RESTATEMENT (SECOND) OF CONFLICT OF LAwS $\$ 283(2)$ (1971). For a discussion of application of this exception, see infra Part II.B.

${ }^{21}$ See H.R. REP. No. 104-664, at 2 (1996) (describing the second primary purpose of the DOMA as "protect[ing] the right of the States to formulate their own public policy regarding the legal recognition of same-sex unions"). 
tion. ${ }^{22}$ A background understanding of these subjects highlights the constitutional infirmities of section 2 of the DOMA.

Part I of this Comment discusses the drafting and interpretation of the Full Faith and Credit Clause, and describes its coordination with conflict-of-laws rules. The application of these combined doctrines to extraterritorial marriages, generally ensuring their recognition by sister states, is outlined in Part II. Part III provides a discussion of the forces behind, and against, same-sex marriages, including the policy reasons advanced against recognition of these unions. Part IV describes the text and legislative history of the DOMA as revealing both the motives and constitutional concerns of the members of Congress. Part V summarizes these issues in an analysis of the constitutionality of the DOMA. It concludes that section 2 of the Act should be found unconstitutional on the grounds that it exceeds Congress's power to legislate, by "general Laws," under the Full Faith and Credit Clause and that it unduly interferes with the status of the states as independent sovereigns. ${ }^{23}$

${ }^{22}$ Section 2 of the DOMA gives no additional power to a state which has a strong, established public policy against same-sex marriage and which is considering the validity of a marriage in which it has significant interest. However, if a state does not have a strong public policy established against same-sex marriage, the DOMA purports to grant states the right to deny recognition of another state's marriage when it might not otherwise have the power to do so. Thus, courts would not have to point to an existing public policy in order to invalidate a same-sex marriage. Relieved of their usual burden under a choice-of-law analysis, judges will be more likely to deny recognition of another state's same-sex marriage. In addition, courts will not likely be presented with alternative state legislation authorizing recognition, the passage of which is currently politically infeasible. Thus, the net effect of the Act will be to frustrate the recognition of same-sex marriages. This argument will be discussed in more detail in Part V.B.

${ }^{23}$ The DOMA is constitutionally suspect on other grounds as well: It may unduly interfere with the right to travel or violate equal protection in the wake of Romer $v$. Evans, 116 S. Ct. 1620, 1629 (1996) (invalidating, on equal protection grounds, legislation that would have prevented the extension of non-discrimination protection to homosexuals). It may also conflict with the requirements of the Due Process Clause. See Allstate Ins. Co. v. Hague, 449 U.S. 302, 308 (1981) (noting that the Court has, under the Due Process Clause, "invalidated the choice of law of a State which has had no significant contact or significant aggregation of contacts, creating state interests, with the parties and the occurrence or transaction"). A discussion of these alternative constitutional challenges is beyond the scope of this Comment. 


\section{THE Full FAITH AND CREDIT ClAUSE}

\section{A. History and Evolution}

Although a substantial amount of scholarly attention has been paid to the history of the Full Faith and Credit Clause, ${ }^{24}$ the information surrounding the drafting of the Clause is sparse. Prior to the Revolution, a colony confronted with a statute or judgment from another colony would usually decline to recognize the statute or judgment and would resolve the issue anew. ${ }^{25}$ The Articles of Confederation included a provision similar to its constitutional successor. $^{26}$ This provision may have represented an attempt to militate against the disregard, inherited from England, for extraterritorial enactments or decisions. ${ }^{27}$ This initial provision in the Articles differed, however, from the Full Faith and Credit Clause in that it lacked a grant of power to Congress ${ }^{28}$ and was interpreted and applied as a strictly evidentiary rule. ${ }^{29}$ The somewhat tepid success of

${ }^{24}$ See, e.g., Walter Wheeler Cook, The Powers of Congress Under the Full Faith and Credit Clause, 28 YALE L.J. 421 (1919); Edward S. Corwin, The "Full Faith and Credit" Clause, 81 U. PA. L. REV. 371 (1933); Robert H. Jackson, Full Faith and Credit-The Lauyer's Clause of the Constitution, 45 ColuM. L. REV. 1 (1945); Kurt H. Nadelmann, Full Faith and Credit to Judgments and Public Acts: A Historical-Analytical Reappraisal, $56 \mathrm{MICH}$. L. REV. 33 (1957); James D. Sumner, Jr., The Full-Faith-and-Credit Clause-Its History and Purpose, 34 OR. L. ReV. 224 (1955); Ralph U. Whitten, The Comstitutional Limitations on State Choice of Law: Full Faith and Credit, 12 MEM. ST. U. L. REV. 1 (1981) [hereinafter Whitten I]; Ralph U. Whitten, The Constitutional Limitations on State-Court Jurisdiction: A Historical-Interpretative Reexamination of the Full Faith and Credit and Due Process Clauses (Part One), 14 CREIGHTON L. REV. 499 (1981) [hereinafter Whitten II].

${ }^{25}$ See Sumner, supra note 24, at 226-27 (describing the almost total lack of recognition afforded to legislation and jucicial proceedings from either a foreign colony or nation); Whitten II, supra note 24, at 527-35 (providing a detailed account of the interaction among the colonies leading up to the drafting of the Articles of Confederation).

${ }^{26}$ See ARTICLES OF CONFEDERATION art. IV (U.S. 1778).

${ }^{27}$ See Sumner, supra note 24, at 228 ("By the time of the Continental Congress we can assume that many people, in particular the lawyers, were of the opinion that a more civilized attitude should be taken towards the acts of other colonies."). But see Nadelmann, supra note 24, at 48-49 (questioning whether the provision was intended as more than an evidentiary rule); Whitten I, supra note 24, at 31 (arguing that the provision "addressed only a limited evidentiary command to the states").

${ }^{23}$ See Cook, supra note 24 , at $423-24$ (noting that Congress was powerless to define the meaning of "full faith and credit" through legislation).

${ }^{29}$ See Sumner, supra note 24 , at 230 (noting that courts held the rule to be "nothing more than a rule of evidence"). 
this initial provision prompted the members of the Constitutional Convention to set out to craft a better solution. ${ }^{30}$

Thus, when it came time to draft the version for the Constitution, the initial clause provided that, "[f]ull faith shall be given in each State to the acts of the Legislatures, and to the records and judicial proceedings of the Courts and Magistrates of every other State." The suggestion by James Madison to authorize Congress "to provide for the execution of Judgments in other States"32 led to the proposal of the following provision: "and the Legislature shall by general laws prescribe the manner in which such acts, Records, \& proceedings shall be proved, and the effect which Judgments obtained in one State, shall have in another." When the clause reached its final form, the word "shall" had been replaced with "may," and the power of Congress had been extended to "prescrib[ing] the effect" of acts, records, and judicial proceedings. ${ }^{34}$ The drafters made this latter change over the protest of $\mathrm{Mr}$. Randolph, a convention member from Virginia, that "its definition of the powers of the Government was so loose as to give it opportunities of usurping all the State powers." This history, albeit brief, strongly suggests that the drafters were cautious about extending the authority of Congress. ${ }^{36}$ In addition, the drafters intended the Clause to unify the newly joined states into a nation. The Supreme Court has recognized this underlying purpose:

The Full Faith and Credit Clause is not to be applied, accordion-like, to accommodate our personal predilections. It substituted a command for the earlier principles of comity and thus basically altered the status of the States as independent sovereigns. It ordered submission by one State even to hostile policies reflected in the judgment of another State, because the practical operation of the federal system, which the Constitution designed, demanded it. ${ }^{37}$

so See id. at 243 (asserting that "[ $\mathrm{t}]$ he accounts of the convention proceedings clearly show that the writers of the [Constitution] sought to eliminate the freedom of the states in disregarding the official acts of sister states").

${ }^{31}$ See 2 THE RECORDS OF THE FEDERAL CONVENTION OF 1787, at 188 (Max Farrand ed., 1st ed. 1911) [hereinafter Farrand].

32 See id. at 448.

$3 s$ See id. at 485.

34 See Cook, supra note 24, at 425-26.

${ }^{35}$ Farrand, supra note 31 , at $488-89$.

${ }^{96}$ See Whitten II, supra note 24, at 549-50 (referring to James Madison's belief that authorizing Congress to provide for the execution, as opposed to evidence, of judgments "might be safely done and was justified by the nature of the Union" (quoting Farrand, supra note 31, at 448)).

${ }^{37}$ Estin v. Estin, 334 U.S. 541, 545-46 (1948) (citations omitted). 
Having been granted the authority to legislate, Congress promptly provided for the means of authenticating public acts and judicial records and proceedings in the Act of May 26, 1790. ${ }^{38}$ The Act passed quickly; if there was any debate over its passage, there is no record of it. ${ }^{39}$ Shortly thereafter, in the Act of March 27, 1804, Congress provided for the authentication of non-judicial records and expanded the reach of the implementing act to include the territories of the United States. ${ }^{40}$

During the infancy of the Full Faith and Credit Clause, there was considerable debate about how to interpret the Clause and its implementing act, focusing primarily on whether they were intended to be discretionary or self-executing. ${ }^{41}$ Because courts had interpreted "full faith and credit," as used in the Articles of Confederation, to be an evidentiary rule, they initially adopted this interpretation when applying the constitutional provision. ${ }^{42}$ The Supreme Court finally resolved the debate in Mills v. Duryee, in favor of regarding the Clause as self-executing and conclusive, rather than as a mere evidentiary rule. ${ }^{43}$ The dissent by Justice Johnson objected that the decision left

ss 1 Stat. 122.

${ }^{39}$ See Nadelmann, supra note 24, at 60 \& n.124 (commenting on the lack of records).

${ }^{10} 2$ Stat. 298. See Sumner, supra note 24, at 235-36 (describing Congress's early legislation under the Full Faith and Credit Clause). In 1948, Congress incorporated these two acts, which earlier had been merged into one provision, into the United States Code. See Act of June 25, 1948, Pub. L. No. 773, 62 Stat. 869, 947 (codified at 28 U.S.C. $\$ 1738$ (1994)).

11 See Douglas Laycock, Equal Citizens of Equal and Territorial States: The Constitutional Foundations of Choice of Law, 92 CoLUM. L. REV. 249, 292-95 (1992) (arguing that the drafting record demonstrated the explicit intention to have the Clause be selfexecuting); Nadelmann, supra note 24, at 62-71 (discussing the early nineteenthcentury debate); Whitten II, supra note 24, at 552-67 (concluding the Clause was intended as an evidentiary rule and the implementing act rendered it self-executing).

${ }^{42}$ See Whitten II, supra note 24, at 559-65 (describing the interpretive debate from 1790 to 1813 ).

11 U.S. (7 Cranch) 481, $484-85$ (1813). Some commentators have argued that the Supreme Court was interpreting only the implementing act, not the Clause itself. See Whitten I, supra note 24, at 50-51 \& n.257. According to Professor Whitten, the Court incorrectly interpreted the implementing act as conclusive rather than as merely evidentiary. See id. at 50-55; see also Nadelmann, supra note 24, at 68-69 (arguing that the Mills decision was based on the implementing act alone). Justice Story, the author of the Mills opinion, later wrote that, contrary to his Mills opinion, the Clause must be interpreted as selfexecuting, or "otherwise, Congress could have power to repeal or vary the full faith and credit given by the clause." Nadelmann, supra note 24, at 70 (citing 3 JOSEPH STORY, COMMENTARIES ON THE CONSTITUTION OF THE UNITED STATES $§ 1306$ (Boston, Hilliard, Gray, \& Co. 1833)). It has been suggested, however, that if Justice Story had had access to the notes of James Madison at 
states "at liberty to pass the most absurd laws [and it is] out of our power to prevent the execution of judgments obtained under those laws." ${ }^{44}$ As the Court continued to bolster the strength of the Full Faith and Credit Clause, dissenting opinions continued to warn of the dangers of broadly interpreting its scope, ${ }^{45}$ resulting in an uncertain full faith and credit doctrine. Thus, the degree to which a state must recognize "public acts, records and judicial proceedings" of sister states is "still disput[ed]." Part of this uncertainty stems from the exceptions created as the full faith and credit doctrine evolved. Although the public acts and records of one state generally are given full faith and credit in every other state, such credit may be denied if doing so would contravene a public policy of the forum state. ${ }^{47}$

Judgments, in contrast, have been accorded much greater deference and are entitled to the most stringent full faith and credit requirements. ${ }^{48}$ Circumspection regarding judgments dates back to

the time of this writing, he might have interpreted the Clause differently. See id. (noting that Justice Story did not know of the change in the language from "ought" to "shall"); Whitten I, supra note 24, at $51 \mathrm{n} .257$ (noting that Justice Story did not have Madison's notes). Regardless of the correctness of the Mills decision, it has been firmly established in full faith and credit jurisprudence that the Clause is conclusive. See Jackson, supra note 24, at 11 ("[T] he Constitutional [Full Faith and Credit] provision must now be regarded as self-executing ...."). This interpretation does not end the matter, however, as the exceptions to the rule are just as firmly established. See infra notes 47-48 (explaining several exceptions).

${ }^{11}$ Mills, 11 U.S. at 486-87 (Johnson, J., dissenting).

${ }^{15}$ See, e.g., Fauntleroy v. Lum, 210 U.S. 230 (1908). In this case, the Court held that Mississippi was bound by a Missouri court decision that enforced a gambling contract performed in Mississippi in violation of its public policy. See id. at 237. The Court determined that, although the Missouri court based its decision on an erroneous interpretation of Mississippi state law, the courts of Mississippi were required to give Missouri's judgment full faith and credit. See id. The dissent argued that "the effect will be to endow each State with authority to overthrow the public policy ... of the others." Id. at 239 (White, J., dissenting).

${ }^{16}$ Cook, supra note 24 , at 421 .

${ }^{17}$ See Alaska Packers Ass'n v. Industrial Accident Comm'n, 294 U.S. 532, 547 (1935) (holding that the Full Faith and Credit Clause does not require states to enforce statutes that contravene their public policy). This public policy exception, however, is not unlimited. See Phillips Petroleum Co. v. Shutts, 472 U.S. 797, 822 (1985) (finding that the forum state had insufficient interest in the claims being litigated to apply its own law rather than the laws of other states).

${ }^{48}$ See, e.g., Magnolia Petroleum Co. v. Hunt, 320 U.S. 430, 437 (1943) ("The full faith and credit clause and the Act of Congress implementing it have, for most purposes, placed a judgment on a different footing from a statute of one state, judicial recognition of which is sought in another."), overruled on other grounds by Thomas v. Washington Gaslight Co., 448 U.S. 261 (1980); Brainerd Currie, Full Faith and Credit, Chiefly to Judgments: A Role for Congress, 1964 SuP. CT. REV. 89, 91-109 (comparing the full faith and credit accorded to public acts with that accorded to judgments). 
the Constitutional Convention, when James Madison "wished the Legislature might be authorized to provide for the execution of Judgments in other States." largely predicated on the doctrine of res judicata, which precludes a collateral attack on a judgment or an issue decided therein once fully litigated. This principle demonstrates respect for the courts of the deciding state and provides finality to judgments and security to the parties involved. . $^{0}$

Cognizant of this preferential treatment of judgments, and concerned that a same-sex couple might bolster the validity of their marriage with a judgment, Congress expressly included judgments within the ambit of the DOMA. ${ }^{51}$ A marriage probably would be regarded as either a public act or record. ${ }^{52}$ In many states, however, the marital status of the parties is an appropriate matter for declaratory judgment. $^{53}$ A judgment of marital status also might arise in collateral disputes. ${ }^{54}$

Throughout this development of full faith and credit, and up to the present, the Supreme Court has been uncharacteristically silent on the issue of Congress's power under the Clause, although this reticence can be attributed largely to Congress's rare invocations of its power to legislate under the Clause. The Act of May 26, 1790, dis-

Even judgments are not given full faith and credit without exception. For example, the Supreme Court quickly excepted the recognition of judgments made on improper jurisdiction from the demands of full faith and credit, see Thompson v. Whitman, 85 U.S. (18 Wall.) 457, 468-69 (1873) (holding that "the jurisdiction of the court by which a judgment is rendered in any State may be questioned in a collateral proceeding in another State ${ }^{n}$ ), and has recognized a limited public policy exception to the recognition of extraterritorial judgments, see Alaska Packers Ass'n, 294 U.S. at 546 ("[T]here are some limitations upon the extent to which a state will be required by the full faith and credit clause to enforce even the judgment of another state, in contravention of its own statutes or policy.").

19 Farrand, supra note 31, at 448.

${ }^{\text {so }}$ See, e.g., Brown v. Felsen, 442 U.S. 127, 131 (1979) (noting that the doctrine of res judicata "encourages reliance on judicial decisions, bars vexatious litigation, and frees the courts to resolve other disputes").

${ }^{51}$ See H.R. REP. NO. 104-664, at 28-29 (1996) (noting that section 2 of the DOMA applies to any public act, record, or judicial proceeding).

${ }_{52}$ See id. at 37 (noting that "it would appear from the face of the [Full Faith and Credit] clause [that marriages] should be afforded full faith and credit as either Acts or Records").

${ }^{33}$ See, e.g., Hager v. Hager, 349 S.E.2d 908, 909 (Va. Ct. App. 1986) (declaring a marriage invalid); 26 C.J.S. Declaratory Judgments $§ 38$ (1956) ("The marital status of the parties is a proper subject for declaratory relief.").

${ }^{34}$ See 1 LYNN WARDLE ET AL., CONTEMPORARY FAMILY LAW $\S 2.03$, at 16 (1988) ("Frequently the issue of marriage validity arises collaterally...."). 
cussed earlier, ${ }^{55}$ was Congress's first exercise of this power. Since that time, Congress has enacted legislation under the Full Faith and Credit Clause on only three other occasions. ${ }^{56}$ Exacerbating this lack of congressional attention is the Supreme Court's infrequent discussion of the Clause's purpose. ${ }^{57}$ As the Court has not offered much guidance with respect to the Full Faith and Credit Clause, the result has been a potpourri of state court decisions applying the Clause against the background of the applicable choice-of-law rules. We now turn to this relationship.

\section{B. Coordination with the Conflict-of-Laws Doctrine}

The full faith and credit doctrine, as expressed in both the Clause and its implementing act, was established against a background of conflict-of-laws rules, and there is considerable evidence that the Framers expected it to be applied within such a context. ${ }^{58}$ Every state has enacted choice-of-law rules. When confronted with an extraterritorial act, proceeding, or judgment, states first examine their own choice-of-law rules to determine what law to apply. ${ }^{59}$ Usually, this results in the forum state deciding what effect the state with the greatest interest would give to the judgment, and applying that effect. $^{60}$ The two complementary doctrines of full faith and credit and conflict-of-laws work together. As shall be discussed shortly, this set of

${ }^{35}$ See supra text accompanying notes 38-39.

${ }^{56}$ See 18 U.S.C. $\$ 2265$ (1994) (full faith and credit given to protection orders); 28 U.S.C. $\$ 1738$ A (1994) (full faith and credit given to child custody determinations); 28 U.S.C. $\$ 1738 \mathrm{~B}$ (1994) (full faith and credit given to child support orders).

${ }^{37}$ See Laycock, supra note 41 , at 257 (criticizing the Court for "a long period of inconclusive decisions" that led to the Court "all but abandon [ing] the field").

${ }^{58}$ See, e.g., Sun Oil Co. v. Wortman, 486 U.S. 717, 723 n.1 (1988) (referring to the "conflicts law embodied in the Full Faith and Credit Clause"); Laycock, supra note 41, at 289-90 (arguing that the Framers assumed that choice-of-law rules would be applied in the application of the Full Faith and Credit Clause).

A House Report on the DOMA states that "Section 2 does not ... determine the choice-of-law issue . . . . But Section 2 does mean that the Full Faith and Credit Clause will play no role in that choice of law determination ..." H.R. REP. NO. 104-664, at 25-26 (1996).

${ }^{59}$ EUGENE F. SCOLES \& PeTER HAY, CONFLiCT OF LAWS $§ 3.1$, at 49 (2d ed. 1992).

${ }^{60}$ See RESTATEMENT (SECOND) OF CONFLICT OF LAWS $\$ 6$ (1971); see also Laycock, supra note 41, at 253 (describing how the Second Restatement "directed courts to apply the law of the state with the most significant relationship to the controversy, after considering every factor thought to be relevant under any theory then extant"). 
doctrines has produced great variety, and confusion, among the states regarding the recognition of extraterritorial marriages. ${ }^{61}$

\section{CONFLICT OF LAWS AND MARRIAGE}

\section{A. Lex Loci Celebrationis and the Presumption of the Validity of Marriage}

In general, there is a rebuttable presumption that marriages, once performed, are valid. ${ }^{62}$ The Restatement (Second) of Conflict of Laws states the general rule, often cited, that a marriage that is valid in the performing state will be recognized as valid in all other states. ${ }^{63}$ The rule is referred to as lex loci celebrationis or lex loci contractus. ${ }^{64}$ Reinforcing this general doctrine are various policy arguments advanced for the presumption of validity of marriages, ${ }^{65}$ and in particular for marriages that involve children.

Marriage entails many legal rights and responsibilities, but also implicates matters of great intimacy. Therefore, the treatment of marital relationships demands great protection for the interests of both the married individuals and the state in which the couple resides. ${ }^{67}$ In this way, the treatment of marriage is unique within the

${ }^{61}$ See infra notes 70-78 and accompanying text.

${ }^{62}$ See generally LENNART PÅLSSON, MARRIAGE IN COMPARATIVE CONFLICT OF LAWS: SUBSTANTIVE CONDITIONS 7-79 (1981).

69 RESTATEMENT (SECOND) OF CONFLICT OF LAWS \$ 283(2) (1971).

${ }^{64}$ See 55 C.J.S. Marriage $\S 4$ (b) (1948) ("The general rule is that the validity of a marriage is determined by the law of the place where it was contracted."); see also Loughran v. Loughran, 292 U.S. 216, 223 (1934) (applying the lex loci contractus rule).

${ }^{65}$ See RESTATEMENT (SECOND) OF CONFLICT OF LAWS $\$ 283(2) \mathrm{cmt}$. b (1971) ("[T]he protection of the justified expectations of the parties is of considerable importance in the case of marriage ...."); SCOLES \& HAY, supra note $59, \S 13.2$, at 431 (describing the strong policy of validating marriages that are freely entered); RUSSELI J. WEINTRAUB, COMMENTARY ON THE CONFLICT OF LAWS $\$ 5.1 \mathrm{C}$, at 233-36 (3d ed. 1986) (enumerating reasons for policy of validation).

${ }^{66}$ See PÁLSSON, supra note 62, at 13 (stating that American policy is to uphold "the legitimacy of children born of the union").

${ }^{67}$ See, e.g., Williams v. North Carolina, 325 U.S. 226, 229 (1945) (asserting that the marriage "[d]omicil implies a nexus between person and place of such permanence as to control the creation of legal relations and responsibilities of the utmost significance"). The Court also noted that marriage "is of concern not merely to the immediate parties. It affects personal rights of the deepest significance. It also touches basic interests of society. ... [E]very consideration of policy makes it desirable that the effect should be the same wherever the question arises." Id. at 230 . In the same case, however, the Court noted that "[ $t]$ he domicil of one spouse within a State gives power to that State ... to dissolve a marriage wheresoever contracted." Id. at 229-30. 
conflict-of-laws rules. Individuals who marry have an obvious interest in the recognition of their union. States have an equally strong interest in regulating marriage within their borders. ${ }^{68}$ These interests are often antagonistic, and may be further complicated if the interests of more than one state are implicated. ${ }^{69}$

As with any conflict-of-laws issue, states look to their own choiceof-laws rules in applying the doctrine of lex loci. ${ }^{70}$ Many states have specifically adopted statutes regarding the recognition of extraterritorial marriages. ${ }^{71}$ For example, seventeen states have adopted a strict lex loci rule." Other states have adopted "evasion" or other limiting statutes that govern recognition of marriages formed in other states solely for the purpose of evading the laws of the domicile state. ${ }^{73}$ In analyzing whether a same-sex marriage would be recognized, careful attention must be paid to the choice-of-laws rules existing in the state involved. This is particularly the case with regard to that state's rules governing the public policy exception to the full faith and credit doctrine. ${ }^{74}$

\section{B. The Public Policy Exception: Applications and Limitations}

The Restatement (Second) of Conflict of Laws provides that a marriage may not be recognized if such recognition "violates the strong public policy of another state which had the most significant relationship to the spouses and the marriage at the time of the marriage. ${ }^{75}$ Thus, when confronted with an extraterritorial marriage, the

${ }^{6}$ See, e.g., Sherrer v. Sherrer, 334 U.S. 343, 354 (1948) (stating that "the regulation of the incidents of the marital relation involves the exercise by the States of powers of the most vital importance").

${ }^{69}$ See SCOLES \& HAY, supra note 59, $\$ 13.15$, at 455 (addressing those situations involving more than one domicile).

${ }^{70}$ See, e.g., RESTATEMENT (SECOND) OF CONFLICT OF LAwS $\$ 283(2) \mathrm{cmt}$. k (1971) ("The forum will apply its own legal principles in determining whether a given policy is a strong one within the meaning of the present rule."); SCOLES \& HAY, supra note $59, \S 3.1$, at 49 ("[T] he choice-of-law rule determining which state's law is to be used, ordinarily is a rule of the law of the forum." (footnote omitted)); WARDLE ET AL., supra note 54, $\S 3.03$, at 9 ("The first rule in 'choice-of-law' questions regarding marriage formalities is that a court will follow the law of its own jurisdiction.").

7 See WARDLE ET AL., supra note 54, § 3.03 , at 9 .

${ }^{72}$ See id. $\S 3.03$, at 9 \& n.3.

73 See id. $\$ 3.03$, at $9 \&$ n. 4 .

${ }^{74}$ For a discussion of the expected treatment of extraterritorial same-sex marriages, see sources cited infra note 117.

75 RESTATEMENT (SECOND) OF CONFLICT OF LAWS $\$ 283(2)$ (1971). For a criticism of the public policy exception, see Laycock, supra note 41, at 313-15. 
forum state must determine if the state with the most interest in the marriage has a public policy sufficiently strong to invalidate the marriage. ${ }^{76}$ A state's public policy is generally expressed in its positive

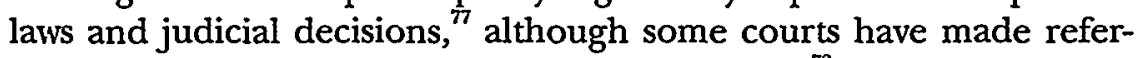
ence to the public policy suggested by natural law. ${ }^{78}$

The Restatement provides a series of rules to apply in determining the state with the greatest interest in the marriage, ${ }^{79}$ but in most cases, "it is the domicile of the parties immediately following the purported marriage. ${ }^{80}$ The domicile of the individuals is thus crucial to any conflict-of-laws analysis. A state is presumed to have the strongest interest, relative to other states, regarding the marital relations of its residents. ${ }^{81}$ The domicile rule would clearly encompass a situation in which residents of one state went to Hawaii to get married and then returned to their home state. In such an instance, the domicile state would have the discretion to deny recognition of the Hawaiian marriage, provided that it had a sufficiently strong public policy against same-sex marriages. ${ }^{82}$ It is not clear, however, whether

${ }^{76}$ See RESTATEMENT (SECOND) OF CONFLICT OF LAWS $§ 283$ (2) cmt. k (1971) (“[A] marriage which satisfies the requirements of the state where it was contracted will be held valid everywhere except when its invalidation is required by the strong policy of another state which had the most significant relationship to the spouses and the marriage at the time of the marriage."). If a state's public policy against the union is insufficiently strong, the marriage must be recognized. See, e.g., Bogen v. Bogen, 261 N.W.2d 606, 609 (Minn. 1977) (finding that the state's public policy against marriage within six months of divorce was not strong enough to warrant nonrecognition of the extraterritorial marriage). For a discussion of the treatment of marriages between parties with different domiciles, see SCOLES \& HAY, supra note $59, \S 13.15$, at 455-56.

7 See, e.g., Sirois v. Sirois, 50 A.2d 88, 89 (N.H. 1946) (locating the state's public policy in the common law and statutes); Taliaferro v. Rogers, 248 S.W.2d 835, 838 (Tenn. Ct. App. 1951) (finding public policy in the state's constitution, statutes, and common law).

${ }^{78}$ See, e.g., Roston v. Folsom, 158 F. Supp. 112, 118 (E.D.N.Y. 1957) (refusing to recognize a bigamous marriage on grounds that bigamy offends natural law).

79 See RESTATEMENT (SECOND) OF CONFLICT OF LAWS $§ 6$ (1971).

${ }^{B 0}$ Mpiliris v. Hellenic Lines, Ltd., 323 F. Supp. 865, 877 (S.D. Tex. 1969) (asserting that the state of intended domicile is the state with the greatest interest in the marriage), affd, 440 F.2d 1163 (5th Cir. 1971); see also SCOLEs \& HAY, supra note 59, § 13.8, at 444 (" $[\mathrm{T}]$ he domicile of the parties immediately following the purported marriage ... usually is most concerned with the validity of the marriage ....").

${ }^{81}$ See Williams v. North Carolina, 317 U.S. 287, 296 (1942) (stating that it was "difficult to perceive how North Carolina could be said to have an interest in Nevada's domiciliaries superior to the interest of Nevada"). An important aspect of this interest is reflected in the state's strong interest in having its marriages recognized by other states. See, e.g., Restatement (SECOND) OF CONFLict OF LAWS $\S 283 \mathrm{cmt}$ i (1971) ("Upholding the validity of a marriage is ... a basic policy in all states.").

${ }^{82}$ See supra note 76 and accompanying text. 
this rule would cover a situation in which a same-sex couple was domiciled in Hawaii both before and after the wedding and changed its domicile years later. Initially at least, the state with the most interest in the marriage would be Hawaii, in which case another state would have to recognize the marriage in the manner Hawaii would. ${ }^{83}$ This would be so "even if the marriage is contrary to the lex fori and perhaps regarded as highly distasteful by that law." ${ }^{84}$ States have thus recognized marriages that were strongly repugnant to their own public policy, such as those involving incest or minors. ${ }^{85}$

There is even stronger support for the recognition, due to full faith and credit, of the incidents of an extraterritorial marriage. Traditionally, states have been more amenable to recognizing a marriage that is contrary to their public policy for the purpose of granting incidental rights. ${ }^{86}$ To illustrate, assume that a same-sex married couple from Hawaii went on vacation in California and was involved in a car accident that killed one spouse. The surviving spouse wants to sue the negligent California driver who caused the accident. Normally, California would recognize the validity of the marriage for the purpose of resolving the wrongful death claim, even

${ }^{8 s}$ See, e.g., Gorrasi v. Manzella, 191 N.E. 676, 677 (Mass. 1934) (holding that, where a married couple had never resided in the state, Massachusetts law could not be applied to determine the marriage's validity). Once a couple changes domicile, the interest analysis may change. The longer a couple resides in a state as a married couple, the greater becomes that state's interest in their marital status. See, e.g., In re Marriage of Reed, 226 N.W.2d 795, 796 (Iowa 1975) (asserting that the court should apply the choice-of-law rules of the state in which a couple cohabited longer).

${ }_{84}$ PÁLSSON, supra note 62, at 35.

${ }^{85}$ See, e.g., In re May's Estate, 114 N.E.2d 4, 6-7 (N.Y. 1953) (recognizing another state's marriage, deemed incestuous by the laws of the forum, between an uncle and his niece); see also PẢLSSON, supra note 62, at $36 \mathrm{n} .101$ (citing cases in which marriages were recognized even though contrary to the strong public policy of the forum state); Anthony Dominic D'Amato, Note, Conflict of Laws Rules and the Interstate Recognition of Same-Sex Marriages, 1995 U. ILL. L. REV. 911, 918-21 (summarizing cases involving public policy exceptions). For a thorough, if not particularly current, compilation of cases dealing with this issue, see Annotation, Public Policy of Forum Against Recognition of Marriage Valid (or Voidable Only) by the Law of the Place Where It Was Celebrated, As Affected by Fact That Neither of the Parties Was Domiciled at the Forum at the Time of the Marriage, 127 A.L.R. 437 (1940).

${ }^{86}$ See, e.g., In re Estate of Crichton, 228 N.E.2d 799, 806 (N.Y. 1967) (recognizing property rights in a couple whose marriage was otherwise invalid); WEINTRAUB, supra note $65, \S 5.1 \mathrm{~B}$, at 233 (" $[\mathrm{W}]$ hether a specific incident of . . marriage may be enjoyed in a particular state depends upon whether enjoyment of the incident would offend a strongly-held public policy of that state."). 
if that marriage was strongly repugnant to its public policy. ${ }^{87}$ This result may be viewed as a compromise between the competing interests of the marital domicile and the forum state. In the hypothetical, Hawaii has a strong interest in having the validity of its citizens' marriages recognized. California has a significant interest in enforcing its negligence laws. Because California will not be recognizing the marriage as an ongoing relationship, recognition for the limited purpose of a lawsuit does insufficient violence to California's public policy to warrant nonrecognition.

Under this standard, states have recognized marital incidents for limited purposes even when the underlying marriage would have been denied recognition on strong public grounds-for instance, in cases of marriage involving incest, minors, or even polygamy. ${ }^{88}$ Thus, even if a state had a strong public policy against same-sex marriages, it would likely recognize at least some of the incidents of such a marriage. $^{89}$ The DOMA explicitly grants states the right to deny recognition of even the incidents of a same-sex marriage from another state. ${ }^{90}$ Thus, even when a state has no interest in an underlying extraterritorial marriage, as in the hypothetical case described above, the DOMA grants that state absolute power to deny recognition of the

${ }^{87}$ See WARDLE ET AL., supra note $54, \S 3.03$, at 12 (describing how a court "could properly determine ... that some parties are entitled to enjoy the incident of marriage even though they do not satisfy the requirements for status of marriage").

${ }^{28}$ See, e.g., Estate of Hafner v. Hafner, 229 Cal. Rptr. 676, 677 (Cal. Ct. App. 1986) (recognizing a bigamous marriage for the purpose of distributing the husband's estate); May's Estate, 114 N.E.2d at 7 (recognizing an uncle-niece marriage for purpose of administering the deceased wife's estate); RESTATEMENT (SECOND) OF CONFLICT OF LAws $\$ 284 \mathrm{cmt}$. c (1971) ("[A] state may prohibit the parties to a polygamous marriage from cohabiting within its territory. Yet it may recognize... the economic interests of the spouses ...."). But see Marianacci v. Marianacci, 299 N.Y.S. 146, 148 (N.Y. Fam. Ct. 1937) (refusing to recognize the incidents of a polygamous marriage).

${ }^{89}$ Strengthening this possibility is the acknowledgment by courts, in recent years, of certain rights of same-sex couples. See, e.g., In re Guardianship of Kowalski, 478 N.W.2d 790, 797 (Minn. Ct. App. 1991) (granting guardianship of a severely braindamaged woman to her same-sex partner); Braschi v. Stahl Assocs., 543 N.E.2d 49, 54 55 (N.Y. 1989) (interpreting a New York City rent control ordinance to include samesex life partner as a family member); Small v. Harper, 638 S.W.2d 24, 27-28 (Tex. App. 1982, writ refd n.r.e.) (finding that no public policy considerations precluded a woman from recovering her share of property accumulated during a long-term, lesbian relationship). But see Bone v. Allen (In re Allen), 186 B.R. 769, 774 (Bankr. N.D. Ga. 1995) (denying recognition of same-sex partner as a "spouse" for purposes of bankruptcy proceeding); In re Will of Cooper, 592 N.Y.S.2d 797, 799 (N.Y. App. Div. 1993) (denying right of survivorship to same-sex life partner).

See Defense of Marriage Act $\S 2$ (a), 28 U.S.C.A. $§ 1738 C$ (West Supp. 1997) ("No state ... shall be required to give effect to ... a right or claim arising from such [samesex] relationship."). 
other state's valid marriage. The marital state, with its strong interest in the relationship, has been denied its status as an independent sovereign. ${ }^{91}$ Whatever the Full Faith and Credit Clause means, it does not mean that a state's sovereignty may be so disregarded.

Compounding this slight to state sovereignty is the exception created by the DOMA for the selective nonrecognition of judgments. As noted above, full faith and credit applies most rigorously to judgments. ${ }^{92}$ In spite of the special recognition given to judgments, however, the Supreme Court has acknowledged that "there are some limitations upon the extent to which a state will be required by the full faith and credit clause to enforce even the judgment of another state, in contravention of its own statutes or policy. ${ }^{\text {"93 }}$ Yet "[t]he situations where a judgment of one State has been denied full faith and credit in another State, because its enforcement would contravene the latter's policy, have been few and far between. ${ }^{, 94}$ Indeed, the Court has said that "the requirements of full faith and credit, so far as judgments are concerned, are exacting, if not inexorable. ${ }^{.95}$

Aware of the preferential treatment of judgments, and concerned that a same-sex couple might avail itself of that advantage, Congress explicitly included judgments within the purview of the DOMA. ${ }^{96}$ Thus, although a declaratory judgment as to the validity of a marriage would ordinarily bolster a couple's claim for full faith and credit, the DOMA purports to remove that support. It is therefore unclear whether a declaratory judgment would assist a same-sex couple in another state. To some degree, at least, the extent to which the DOMA will affect the expected recognition of same-sex marriages will

${ }^{91}$ See, e.g., Pennoyer v. Neff, 95 U.S. 714, 722 (1877) ("[E]very State possesses exclusive jurisdiction and sovereignty over persons and property within its territory. As a consequence, every State has the power to determine for itself the civil status and capacities of its inhabitants...."); American Rockwool, Inc. v. Owens-Corning Fiberglas Corp., 640 F. Supp. 1411, 1429 (E.D.N.C. 1986) (asserting that a state's application of its own law must not infringe on another state's sovereignty in violation of full faith and credit).

${ }_{92}$ See supra notes 48-49 and accompanying text.

93 Alaska Packers Ass'n v. Industrial Accident Comm'n, 294 U.S. 532, 546 (1935).

${ }^{94}$ Estin v. Estin, 334 U.S. 541, 545 (1948).

${ }_{95}$ Id. at 546 (footnote omitted). But see Laycock, supra note 41 , at 258 ("As matters stand, the Full Faith and Credit Clause means almost nothing, and state courts can often evade the little that it does mean.").

${ }^{6}$ See H.R. REP. NO. 104-664, at 30 (1996) (noting the possibility that "homosexual couples could obtain a judicial judgment memorializing their 'marriage," as the reason for applying the DOMA to "all three categories of sister-state laws to which full faith and credit must presumptively be given"). 
turn on whether or not the forum state has a strong public policy against same-sex marriages.

\section{SAME-SEX MARRIAGE}

\section{A. A Brief History}

The history of the movement for same-sex marriage is brief but has spawned considerable debate. ${ }^{97}$ The first case addressing the issue of same-sex marriage, Baker $v$. Nelson, arose in $1971 .^{98}$ Since 1971, there have been numerous cases in which a party has sought judicial recognition of the right to same-sex marriage. ${ }^{99}$ Plaintiffs have asserted a variety of claims in seeking the right to same-sex marriage, including claims of fundamental rights, ${ }^{100}$ equal protection violations, ${ }^{101}$ and claims based on equal rights amendments contained in many state constitutions. ${ }^{102}$. All of these attempts have proven unsuccessful.

${ }^{97}$ This debate is not limited to the heterosexual community. See, e.g., RICHARD D. MOHR, A MORE PERFECT UNION $31-53$ (1994) (arguing that same-sex relationships meet the definition of marriage and that gay couples need equal access to the courts). For a discussion of arguments on both sides of the debate within the gay community, see William N. ESKRIDGE, JR., THE CASE FOR SAME SEX MARRIAGE 51-85 (1996); see also LESBIANS, GAY MEN, AND THE LAW 397-406 (William B. Rubenstein ed., 1993) (providing articles regarding the gay community's debate over the marriage issue).

191 N.W.2d 185, 186 (Minn. 1971) (upholding the state practice of issuing marriage licenses exclusively to couples of the opposite sex).

99 See, e.g., Dean v. District of Columbia, 653 A.2d 307 (D.C. 1995) (per curiam) (upholding the denial of a marriage license to a same-sex couple); Jones v. Hallahan, 501 S.W.2d 588 (Ky. 1973) (same); Storrs v. Holcomb, 645 N.Y.S.2d 286 (N.Y. Sup. Ct. 1996) (same); Singer v. Hara, 522 P.2d 1187 (Wash. C. App. 1974) (same); see also Adams v. Howerton, 486 F. Supp. 1119 (C.D. Cal. 1980) (denying recognition of marriage ceremony between two men as basis for citizenship rights), aff', $673 \mathrm{F.2d}$ 1036 (9th Cir. 1982); In re Will of Cooper, 592 N.Y.S.2d 797, 798 (N.Y. App. Div. 1993) (denying right of survivorship for same-sex life partner); De Santo v. Barnsley, 476 A.2d 952 (Pa. Super. Ct. 1984) (refusing to recognize a contract of common-law marriage between two persons of the same sex).

100 See, e.g., Dean, 653 A.2d at 309 (asserting the right to marry); Jomes, 501 S.W.2d at 589 (asserting rights of marriage, association, and free exercise of religion); Storrs, 645 N.Y.S.2d at 287 (asserting a right of privacy).

${ }^{101}$ See, e.g., Dean, 653 A.2d at 333; Baker, 191 N.W.2d at 186; Storrs, 645 N.Y.S.2d at 287; Singer, 522 P.2d at 1188.

${ }_{102}$ See, e.g., De Santo, 476 A.2d at 953 (basing claim on the equal rights amendment adopted in the Pennsylvania state constitution); Singer, 522 P.2d at 1188 (asserting claim based on the Washington state constitution). 
What are the justifications for these decisions? Although some opinions refer to moral ${ }^{103}$ or biological ${ }^{104}$ arguments, most opinions rely on the definition of marriage as being limited to a union between one man and one woman. ${ }^{105}$ These decisions reason that, since marriage has traditionally been understood as involving a man and a woman, two members of the same sex, by definition, cannot marry. ${ }^{106}$ In Jones $v$. Hallahan, the Kentucky court, in an oft-cited opinion, asserted that same-sex couples are "prevented from marrying ... by their own incapability of entering into a marriage as that term is defined." ${ }^{107}$ This argument is patently circular. The court in Baehr $v$. Lewin, in response to the state's definitional argument, "reject[ed] this exercise in tortured and conclusory sophistry." It remains to be seen how states will respond to another state's valid same-sex marriage that defies the traditional definition of marriage.

${ }^{103}$ See, e.g., Adams v. Howerton, 486 F. Supp. 1119, 1123 (C.D. Cal. 1980) (finding that "given the prevailing mores and moral concepts of this age, one could not entertain a good faith belief that he could be married to a person of the same sex").

${ }^{101}$ See, e.g., Singer, 522 P.2d at 1195 (asserting that "marriage exists as a protected legal institution primarily because of societal values associated with the propagation of the human race").

${ }^{105}$ See, e.g., Jones, 501 S.W.2d at 589 (citing Webster's Dictionary as defining marriage as "[a] state of being... united to a person ... of the opposite sex as husband and wife"); Baker, 191 N.W.2d at 186 n.1 (same); De Santo, 476 A.2d at 954 n.1 (citing Webster's Dictionary and Black's Law Dictionary, the latter defining marriage as "the legal union of one man and one woman as husband and wife"); Singer, 522 P.2d at 1192 ("[Plaintiffs] are being denied entry into the marriage relationship because of the recognized definition of that relationship as one which may be entered into only by two persons who are members of the opposite sex.").

${ }^{106}$ One court went even further, stating that a man could not be another man's spouse "any more than a person can simultaneously be man and fish." Slayton v. State, 633 S.W.2d 934, 937 (Tex. App. 1982, no writ). This comparison is misplaced; the biological impossibility of being both a fish and a mammal is not the same as an impossibility created by legal and cultural definitions.

${ }^{107} 501$ S.W.2d at 589.

${ }^{103} 852$ P.2d 44, 63 (Haw. 1993). Relying on a gender-based definition of marriage also raises some interesting problems in deciding a party's gender for marriage purposes. For example, in Anonymous v. Anonymous, 325 N.Y.S.2d 499, 501 (N.Y. Sup. Ct. 1971), the court held that a marriage between two men, when one man thought the other was a woman, was void $a b$ initio, notwithstanding the other man's sex-change operation prior to the annulment proceedings. See also In re Ladrach, 513 N.E.2d 828, 832 (Ohio Prob. Ct. 1987) (upholding denial of marriage license to a man and a postoperative female transsexual). But see M.T. v. J.T., 355 A.2d 204, 211 (N.J. Super. Ct. App. Div. 1976) (holding that a marriage between a man and a post-operative female transsexual was valid). 


\section{B. Public Policy Against Same-Sex Marriage}

In order to understand how a state might apply a public policy exception to the recognition of a same-sex marriage, those public policies disfavoring same-sex unions must be outlined. There are at least three distinct arguments raised against same-sex marriage: the procreation argument, the slippery slope argument, and the fear of validation argument. ${ }^{109}$ The first argument, asserting that marriage is fundamentally about procreation, is frequently invoked against samesex marriages. ${ }^{110}$ The relationship between marriage and procreation is important, but fails as an argument against same-sex marriage for two reasons. First, not all opposite-sex couples have the ability or the desire to procreate; yet this fact would not preclude the recognition of their marriages. Second, many same-sex couples successfully raise both biological and adopted children within a family environment. ${ }^{111}$

The second argument raises the specter of the slippery slope: that to allow same-sex marriages would lead to the destruction of the institution of marriage by permitting polygamous and incestuous relationships." ${ }^{112}$ Again, this argument is flawed. The public policy against polygamy is a protection of monogamy and the stability that monogamy brings to a marital relationship and society. ${ }^{113}$ Same-sex

${ }^{109}$ See ESKRIDGE, supra note 97, at 137-52 (articulating and attacking these arguments).

${ }^{110}$ See, e.g., Frances B. v. Mark B., 355 N.Y.S.2d 712, 717 (N.Y. Sup. Ct. 1974) (referring to the "public policy that the marriage relationship exists with the result and for the purpose of begetting offspring" (citation omitted)).

"II The court in Baehr $v$. Miike found that same-sex couples can, and do, make successful parents. See Baehr v. Miike, CIV. No. 91-1394, 1996 WL 694235, at *17 (Haw. Cir. C. Dec. 3, 1996) ("Gay and lesbian parents and same-sex couples can be as fit and loving parents, as non-gay men and women and different-sex couples."). The court was not persuaded that the quality of care received in same-sex households was significantly different than that received in opposite-sex households. See id. at *18 ("Defendant has not proved that allowing same-sex marriage will probably result in significant differences in the development ... of children ....").

${ }^{112}$ For example, many speakers in the debates over the DOMA portrayed the concept of same-sex marriage as a bandleader for a parade of horribles that would result. Congressman Largent wondered, if same-sex marriages were permitted, "[w] hat logical reason is there to keep us from stopping expansion of that definition to include three people or an adult and a child, or any other odd combination that we want to have? ... [A]nd it doesn't have to be limited to human beings, by the way." 142 CONG. REC. H7443 (daily ed. July 11, 1996) (statement of Rep. Largent).

${ }^{11 s}$ See Reynolds v. United States, 98 U.S. 145, 168 (1878) (upholding conviction for polygamy); Potter v. Murray City, 760 F.2d 1065, 1068 (10th Cir. 1985) (discussing the public policy against polygamy and describing the public policy "commitment to monogamy as the cornerstone of its regulation of marriage" (quoting Potter v. Murray City, 585 F. Supp. 1126, 1137 (D. Utah 1984))). 
couples wish only to have their monogamous relationships given legal force, not to have polygamous same-sex marriages. ${ }^{114}$

The final argument addresses the fear of validation: that to allow same-sex marriages would be to approve or encourage such relationships. ${ }^{115}$ There are two problems with this argument. First, it assumes that homosexuality is a characteristic that can be affected by approbation. Second, even if homosexuality can and should be discouraged, there is reason to doubt the viability of this tack. As the Supreme Court made plain in Romer v. Evans, "'a bare... desire to harm a politically unpopular group cannot constitute a legitimate governmental interest." ${ }^{\prime 116}$ As this brief discussion suggests, none of the anticipated policy arguments against same-sex marriages have merit.

Because no state has been confronted with an extraterritorial same-sex marriage, the use of the public policy exception to deny recognition of such marriages has never been litigated. It is reasonable to assume, however, that many (if not most) states would argue that they have a strong public policy against same-sex marriages. ${ }^{117}$ This sentiment is well-expressed in the state legislatures. Indeed,

114 The inference to incest is even more tenuous, as society presumably has an interest in preventing the birth of genetically inbred offspring. See ESKRIDGE, supra note 97 , at 150 (outlining, but ultimately rejecting, this argument).

${ }^{115}$ Many members of Congress expressed their feelings against homosexuality in strong terms. See, e.g., 142 CONG. REC. S10,110 (daily ed. Sept. 10, 1996) (statement of Sen. Byrd) ("Woe betide that society ... that ... begins to blur that tradition which was laid down by the Creator in the beginning."). A rather extreme expression of this argument also can be found in Justice Scalia's acerbic dissent in Romer v. Evans: "But I had thought that one could consider certain conduct reprehensible-murder, for example, or polygamy, or cruelty to animals-and exhibit even 'animus' toward such conduct. Surely that is the only sort of 'animus' at issue here: moral disapproval of homosexual conduct ...." 116 S. Ct. 1620, 1633 (Scalia, J., dissenting).

${ }^{116} 116$ S. Ct. at 1628 (quoting Department of Agric. v. Moreno, 413 U.S. 528, 534 (1973)). There is considerable tension between this decision and the Court's decision in Bowers v. Hardwick, 478 U.S. 186 (1986), in which the Court upheld the constitutionality of Georgia's criminal sodomy statute as applied to sex between two adult males. Id. at 196. The Court in Romer did not mention Bowers and thus did not expressly overrule it. However, Justice Scalia, in his dissent, insisted that the Romer decision "contradicted" Bowers. Romer, 116 S. Ct. at 1629 (Scalia, J., dissenting).

117 For discussions of the expected extraterritorial treatment of a Hawaiian samesex marriage, see Barbara J. Cox, Same-Sex Marriage and Choice-of-Law: If We Marry in Hawaii, Are We Still Married When We Return Home?, 1994 WIS. L. REV. 1033; Deborah M. Henson, Will Same-Sex Marriages Be Recognized in Sister States?: Full Faith and Credit and Due Process Limitations on States' Choice of Law Regarding the Status and Incidents of Homosexual Marriages Following Hawaii'sBaehr v. Lewin, 32 U. LOUISVILLE J. FAM. L. 551 (1994); Evan Wolfson, Winning and Keeping Equal Marriage Rights: What Will Follow Victory in Baehr v. Lewin?, SUMMARY LEGAL ISSUES (Lambda Legal Defense \& Educ. Fund, New York, N.Y.), Mar. 20, 1996, at 10-11. 
legislation refusing to recognize same-sex marriages has been proposed in thirty-seven states, passed in sixteen states, and remains pending in one. ${ }^{118}$ Legislators from several states have expressed intentions to submit, or re-submit, such legislation. ${ }^{119}$ In addition, cases prior to Baehr in which plaintiffs sought the right to same-sex marriage have met with universal failure. ${ }^{120}$ Lastly, twenty-two states still have laws against sodomy, ${ }^{121}$ which many people interpret as a proxy for distaste of same-sex relationships. ${ }^{122}$

Some indication exists, however, that a few states would not declare a strong public policy against these marriages. For instance, five states have proposed legislation, never passed, to extend marriage rights to same-sex couples. ${ }^{123} \mathrm{~A}$ Wisconsin legislator has also vowed to present a bill granting same-sex marriage rights. ${ }^{124}$ The former gov-

${ }^{\text {"1s }}$ See Andrew Sullivan, Hawaiian Aye: Nearing the Altar on Gay Marriage, NEw REPUBLIC, Dec. 30, 1996, at 15; see also H.R. REP. No. 104-664, at 9-10 \& n.31 (1996) (listing the 14 states that had passed such legislation as of July 11, 1996). The number of states that have passed such legislation is now 18. See Hawaii Seeks Law, supra note 4, at A15. One of the 18 states to have passed such legislation is Hawaii. See Hawaii's Marriage Laws, supra note 4, at 1448 . In redefining the state marriage laws to apply only to opposite-sex couples, the legislature called on the Hawaii trial court to consider the issue then pending on appeal in Baehr $v$. Miike in light of this legislation. See id.

119 See John Sanko, Legislator Will Try Again to Ban Same-Sex Marriages, RoCKY MTN. NEwS, Dec. 5, 1996, at 20A (describing a state representative's intention to reintroduce such legislation in Colorado after Governor Romer vetoed the last attempt); Senator to Oppose Gay Marriages, States News Briefs, Dec. 13, 1996, available in LEXIS, News Library, Curnws File (stating that a state senator intends to "push" legislation in Florida to deny recognition of same-sex marriages because "God created Adam and Eve ... not Adam and Steve").

${ }^{120}$ See, e.g., cases cited supra note 99. For further discussion of the earlier cases, see Peter G. Guthrie, Annotation, Marriage Between Persons of the Same Sex, 63 A.L.R.3d 1199 (1975). laws).

${ }^{121}$ See D'Amato, supra note 85, at 926 \& $\mathrm{n} .99$ (listing states with current sodomy

${ }^{122}$ This is a poor proxy at best. First, many sodomy laws do not limit themselves to acts between members of the same sex. This issue was raised vigorously by the dissent in Bowers $v$. Hardwick against the majority's opinion upholding the constitutionality of Georgia's sodomy laws. See Bowers v. Hardwick, 478 U.S. 186, 200 (Blackmun, J., dissenting) (criticizing "the Court's almost obsessive focus on homosexual activity"). Second, not all same-sex couples engage in sodomy. Lastly, as noted supra note 3, a same-sex couple need not be a homosexual couple.

${ }^{129}$ See 19 States Consider Banning Same-Sex Marriages, Salt LAke TRIB., Apr. 25, 1997, at A20, available in 1997 WL 3402804 (listing the five states as Illinois, Maryland, Nebraska, Rhode Island, and Washington); see also, e.g., L. 1260, 94th Leg., 2d Sess. (Neb. 1995).

124 See David Callender, Gay Leaders Here Hail Marriage Ruling, CAP. TIMES (Madison, Wis.), Dec. 5, 1996, at 2A, available in 1996 WL 13791080 (reporting that state representative Tammy Baldwin intended to introduce such legislation). 
ernor of Massachusetts announced that his state would recognize a same-sex marriage from Hawaii as it would any other extraterritorial marriage, and that he would veto any attempt by the legislature to provide otherwise. ${ }^{125}$ In addition, although no court has ever granted a same-sex couple the right to marry, a few decisions have extended some of the incidents of marriage to same-sex couples. ${ }^{126}$

With the passage of the DOMA, however, Congress has tilted the scales in favor of nonrecognition of same-sex marriages. ${ }^{127}$ Whereas states would ordinarily have consulted their choice-of-law rules when asked to recognize another state's marriage, Congress has provided a means of avoiding this analysis. States no longer have to articulate a sufficiently compelling public policy against recognition of same-sex marriages, nor do they have to assert a significant interest in the marital status of the couple in order to deny recognition of an extraterritorial same-sex marriage.

This differential burden imposed on same-sex marriages may conflict with the Supreme Court's recent decision in Romer, which suggested a shift in the Court's treatment of homosexual issues. ${ }^{128}$ This potential consequence did not go unnoticed in the consideration of the DOMA. For example, Professor Hadley Arkes, in her testimony before the House Committee on the Judiciary, gave ominous portent to the anticipated result in the then-pending Romer decision, asserting that, "many judges ... will extract from that decision this principle: that it is now immanently suspect, on constitutional grounds, to plant, anywhere in the laws, a policy that casts an adverse judgment on homosexuality ...." ${ }^{129}$ As a practical matter, the DOMA will relieve states of both constitutional and comity considerations when confronted with another state's same-sex marriage and thus reduce

${ }^{125}$ See Joe Battenfeld, Gov Would Not Nix Same-Sex Marriages, Boston Herald, Dec. 5, 1996, at Al.

${ }^{126}$ See, e.g., cases cited supra note 89.

${ }^{127}$ As one member of Congress described it:

Which side should have the burden of proof? If Congress does not act, the burden would be on those in opposition to same-sex marriages to affirmatively block them on a State-by-State basis. If Congress passes this legislation, those in support [of] same-sex marriages would have to win recognition of such marriages on a State-by-State basis.

142 CONG. REC. S10,115 (daily ed. Sept. 10, 1996) (statement of Sen. Hatfield).

${ }^{128}$ See William N. Eskridge, Jr., Address at University of Pennsylvania Law School

(Nov. 19, 1996) (notes on file with the University of Pennsylvania Law Review).

${ }^{129}$ Defense of Marriage Act: Hearing on H.R. 3396 Before the Subcomm. on the Constitution of the House Comm. on the Judiciary, 104th Cong. 95-96 (1996) (statement of Professor Hadley Arkes, Amherst College). 
the likelihood of these marriages gaining extraterritorial recognition. ${ }^{130}$ The question remains whether Congress has the constitutional power to do this.

\section{THE DEFENSE OF MARRIAGE ACT}

\section{A. The Text}

The DOMA contains two substantive provisions. The first, section 2 of the Act, which is at issue here, provides as follows:

No State, territory, or possession of the United States, or Indian Tribe, shall be required to give effect to any public act, record or judicial proceeding of any other State, territory, possession, or tribe respecting a relationship between persons of the same sex that is treated as a marriage under the laws of such other State, territory, possession, or tribe, or a right or claim from such relationship.

As an initial matter, it bears emphasis that the legislation does not prevent a state from recognizing another state's same-sex marriage. It does, however, provide that a state does not have to recognize such a union, or the incidents flowing therefrom, ${ }^{132}$ if it so chooses. If we examine the impact of this legislation on a same-sex married couple, the concerns are readily apparent. If a couple from Hawaii moves to California, California may refuse, pursuant to federal law, to recognize their marriage, and deny them all of the associated benefits. ${ }^{1.33}$

${ }^{100}$ Cf. Kery Murakami, Vote Puts Lawmakers in a Bind-Clinton's Stance is Difficult for Those Sympathetic with Gay Rights, SEATTLE TIMES, Feb. 3, 1997, at B1 (describing the concerns state legislators have with voting against legislation like the DOMA for fear of looking too liberal).

191 Defense of Marriage Act $\S 2,28$ U.S.C.A. $\$ 1738 C$ (West Supp. 1997). Congress has never before attempted to provide a means for the nonrecognition of marriages, even in areas that provoke as much opposition as same-sex marriages. This fact did not go unobserved in the legislative debates: "In the nation's history, Congress has never declared that marriages in one state may not be recognized in another; it has not done this for polygamous marriages, marriages among minors, incestuous marriages, or bigamous marriages."” 142 ConG. REC. S10,112 (daily ed. Sept. 10, 1996) (statement of Sen. Boxer) (quoting Professor Cass R. Sunstein).

${ }^{132}$ For a discussion of the differing treatment of marriage and its incidents, see supra notes $86-89$ and accompanying text.

135 See ESKRIDGE, supra note 97, at 2-74 (enumerating and discussing the practical benefits of marriage in this country and the more general, though equally important, advantages, such as broader acceptance by society of homosexual relationships, facilitation of monogamy, and the establishment of a home); see also U.S. GEN. ACCOUNTING OFFICE, REP. No. 16, THE DEFENSE OF MARRIAGE ACT (1997) (reporting that the application of 1,049 federal laws depends on marital status, and enumerating the hundreds of federal benefits that are determined by marital status). 
For example, the state may prohibit one spouse from authorizing lifesaving medical treatment for the other, or force one spouse to testify against the other in a state criminal proceeding. This nonrecognition will not only be performed with the imprimatur of the federal government, but can be exacted in the absence of either a strong public policy against same-sex marriage or a strong interest in the particular marriage at issue.

\section{B. Legislative History: Debates and Testimony}

\section{The Purpose of the DOMA}

The purpose of the DOMA, as described in the report submitted to the Committee of the Judiciary by its sponsor, was to defend the institution of marriage and allow each state to choose whether to recognize same-sex marriages. ${ }^{134}$ The debates, however, yield valuable insights into the real purposes behind the Act and reveal disagreements over many of its aspects. ${ }^{135}$ For example, many proponents of the Act argued that its purpose was to protect states from having to recognize another state's same-sex marriage by application of the Full Faith and Credit Clause. ${ }^{136}$ These individuals thus regarded the legislation as necessary to protect each state's right to regulate marriage within its borders and to not have a repugnant marriage thrust on it against its will. For example, Senator Nickles, a sponsor of the proposed DOMA, argued that "[e]nactment of this bill will allow States to give full and fair consideration of how they wish to address

${ }^{194}$ See H.R. REP. NO. 104-664, at 2 (1996). The report goes on, however, to list other motivations behind House Bill 3396 , including an "interest in children," id. at 13, an "interest in promoting heterosexuality," id. at $15 \mathrm{n} .53$, and a defense of "traditional notions of morality," id. at 15.

${ }^{135}$ The debates also reveal strong disagreement over the entire issue of homosexual relationships in this country, an issue which many feel is the true impetus behind this legislation. The discussion on the floor of the House and Senate was often heated. Opponents referred to the bill as "blatant homophobic gay-bashing," 142 CONG. REC. E1320 (daily ed. July 18, 1996) (statement of Rep. Collins), and proponents argued that "no society... has lived through the transition to homosexuality and the perversion [that it brings] ... forth," id. at H7444 (daily ed. July 11, 1996) (statement of Rep. Coburn). Congressman Coburn frankly asserted that " $[t]$ he real debate is about homosexuality and whether or not we sanction homosexuality in this country." Id. Leaving little doubt about his opinion on the matter, Representative Coburn referred to the belief of his constituency that "homosexuality is immoral, that it is based on perversion, that it is based on lust." Id.

${ }^{136}$ See H.R. REP. NO. 104-664, at 10 (citing the insecurity of states as justification for federal intervention). 
the issue of same-sex marriages instead of rushing to legislate because of fear that another State's laws may be imposed upon them." 197 In contrast, opponents of the bill (many of whom objected to the concept of same-sex marriage) argued that federal legislation was unnecessary because states could resist such recognition if based on a strong public policy of the state. ${ }^{138}$ These individuals also argued that the DOMA could strip a state's valid marriage license or judgment of all extraterritorial force, thus denying like-minded states the opportunity to extend full faith and credit. ${ }^{139}$

197142 CONG. REC. S4870 (daily ed. May 8, 1996) (statement of Sen. Nickles). This remark lends irony to the relative speed at which Congress passed the DOMA. For such an important, and unprecedented, piece of legislation, the deliberation was far from extensive. See id.at H7448 (daily ed.July 11, 1996) (statement of Rep. Conyers) (noting that a bill that was "nothing less than unprecedented" had "gone from introduction, to hearing, to subcommittee, full committee, and now the floor in a mere two month [s'] time"); id. at H7441-42 (statement of Rep. Frank) ("If this is such an important issue, why are we debating this at a quarter to I? I must say that for an important piece of legislation like this to be treated in this fashion is quite shabby.").

The opponents' criticism of the haste was particularly germane, as states will not be faced with the possibility of an extraterritorial marriage for some time. Although the Hawaii state court found that the State must issue marriage licenses to same-sex couples, issuance has been suspended pending a final determination by the Hawaii Supreme Court. See Jonathan Roos, House Panel to Eye Bill Denying Recognition of Gay Marriages, DES MOINES REG., Feb. 21, 1997, at 5, available in 1997 WL 6939468. This move presumably was taken to avoid potential confusion if licenses were issued and then later revoked. Although this case cannot be appealed to the United States Supreme Court, as the decision rests on an interpretation of Hawaii's constitution, a final decision by the Hawaii Supreme Court is unlikely to be reached for at least a year or two. In addition, since the case was initially filed in 1993, 37 states have proposed legislation regarding the recognition of same-sex marriages. See Sullivan, supra note 118 , at 15. Of these, 18 have passed legislation that would deny recognition to extraterritorial same-sex marriages. See Hawaii Seeks Law, supra note 4, at A15. Thus, contrary to the concerns voiced by Senator Nickles, the states appear to be responding to the situation in an efficient manner.

${ }^{139}$ See H.R. REP. NO. 104-664, at 35-36 (describing the dissenting view that states need no protection). Even the report from the House Committee on the Judiciary acknowledged that "the Committee believes that States currently possess the ability to avoid recognizing a same-sex 'marriage' license from another State." Id. at 9. For a discussion of the use of the public-policy exception to deny recognition of extraterritorial marriages, see supra Part II.B.

${ }^{199}$ It is important to recall here that a state's right to refuse recognition of another state's marriage is limited. If the forum state has an insufficient interest in the marriage, it will usually be constrained by the Full Faith and Credit Clause to grant recognition of the marriage. See Allstate Ins. Co. v. Hague, 449 U.S. 302, 308 (1981) (finding that a state must have "significant contact or [a] significant aggregation of contacts" in order to apply its own law); see also Gorrasi v. Manzella, 191 N.E. 676 (Mass. 1934) (holding that, when a married couple had never resided in Massachusetts, that state's law could not be applied to determine the validity of the marriage). 


\section{The Constitutionality of the DOMA}

Much of the debate, as well as the testimony submitted, focused on whether or not the legislation would pass constitutional muster. Although a majority of Congress attested to the Act's validity, ${ }^{140}$ many of the witnesses who testified before the Senate Judiciary Committee, including noted constitutional law scholars, expressed grave doubts about the Act's constitutionality. ${ }^{141}$ The majority of the constitutional debate centered on Congress's power to legislate under the Full Faith and Credit Clause. Supporters of the legislation argued that Congress had not exceeded its authority, drawing support from Congress's recent enactment of several statutes under the Clause. ${ }^{142}$ Opponents countered by arguing that, unlike the recently enacted statutes requiring states to extend full faith and credit to child custody, child support, and protection orders, the DOMA created a narrow categorical exemption from the Full Faith and Credit Clause. ${ }^{143}$

\section{THE UNCONSTITUTIONALITY OF THE DEFENSE OF MARRIAGE ACT}

\section{A. The Meaning of "General Laws" and the Limits of Congress's Power Under the Full Faith and Credit Clause}

\section{1. "General Laws"}

The scope of Congress's power under the Full Faith and Credit Clause is unclear. ${ }^{144}$ The Supreme Court has referred only tangen-

${ }^{140}$ See, e.g., H.R. REP. NO. 104-664, at 26 n.69 (listing statements and reports that found the Act to be constitutional).

${ }^{111}$ See, e.g., The Defense of Marriage Act: Hearings on S. 1740 Before the Senate Judiciary Comm., 104th Cong. 42 (1996) [hereinafter Hearings on Marriage Act] (statement of Professor Cass R. Sunstein, University of Chicago); 142 CoNG. REC. S5931-33 (daily ed. June 6, 1996) (letter from Professor Laurence $H$. Tribe).

${ }^{142}$ See, e.g., 142 CONG. REC. H7274 (daily ed. July 11, 1996) (statement of Rep. Campbell).

${ }_{143}$ See, e.g., id. at H7449 (statement of Rep. Abercrombie). In addition, the fact that Congress has legislated pursuant to the Full Faith and Credit Clause is not conclusive, because the constitutionality of these enactments has never been challenged or addressed by the Supreme Court.

${ }^{144}$ There is considerable agreement among commentators, however, that Congress's power to legislate under the Full Faith and Credit Clause exceeds that which has been exercised. See, e.g., Corwin, supra note 24, at 388 ("[T] here are few clauses of the Constitution, the merely literal possibilities of which have been so little developed as the 'full faith and credit' clause."); Jackson, supra note 24, at 21 (asserting that "it cannot be doubted that Congress is invested with a range of power greatly exceeding that which it has seen fit to exercisen"). 
tially to this authority. In a case determining the effect of the Clause on a divorce decree, the Court remarked, "[w]e, of course, intimate no opinion as to the scope of Congressional power to legislate under Article IV, $\S 1$ of the Constitution.. ${ }^{145}$ In determining the extent of Congress's power to legislate, careful consideration must be given to the phrase "general Laws." Although the drafters appear to have debated how far Congress's power to decide the "effects" of acts, records, and proceedings should extend, both sides of the debate incorporated this "general Laws" language in their proposals. ${ }^{146}$ From this, and from the absence of a generality requirement in any of Congress's other powers, one can reasonably infer that the drafters intended Congress's power under the Clause to be exercised only in broad strokes, and not narrowly to determine the effect of particular

Professor Lynn Wardle, a conflict-of-laws scholar, submitted a written report to the Senate Judiciary Committee, testifying to her opinion of the constitutionality of the proposed DOMA. See Lynn Wardle, Concerning S. 1740: A More Perfect UnionFederalism in American Marriage Law (July 11, 1996) (written statement submitted to the U.S. Senate Judiciary Committee), available in LEXIS, Legis Library, Cngtst File. Although Professor Wardle attested to her belief that the DOMA would not violate the Full Faith and Credit Clause, see id., she conceded that in "rare" situations "in which the [forum] state was totally without any significant contacts or strong public policy, and the only interested state recognized same-sex marriage, full faith and credit might arguably preclude nonrecognition," $i d$.

${ }^{145}$ Sherrer v. Sherrer, 334 U.S. 343,352 n.18 (1948). The Court frequently makes such noncommittal remarks. See, e.g., Williams v. North Carolina, 317 U.S. 287, 303 (1942) ("Whether Congress has the power to create exceptions [based on public policy] is a question on which we express no view." (citation omitted)). But of. Yarborough v. Yarborough, 290 U.S. 202, 215 n.2 (1933) (Stone, J., dissenting) ("The mandatory force of the full faith and credit clause as defined by this Court may be, in some degree not yet fully defined, expanded or contracted by Congress.").

As Professor Tribe pointed out, "judicial precedent ... must be sought in analogous areas." 142 CONG. REC. S5932 (daily ed. June 6, 1996) (letter of Professor Laurence $H$. Tribe). Professor Tribe found an analogy in Section Five of the Fourteenth Amendment, which he described as "another of the Constitution's few clauses expressly authorizing Congress to enforce a constitutional mandate addressed to the States." Id. at S5933. Professor Tribe also noted that the Supreme Court has interpreted Section Five "to mean that Congress may effectuate such a mandate but may not 'exercise discretion in the other direction [by] enact[ing]' statutes that 'dilute' the mandate's self-executing force." Id. (quoting Katzenbach v. Morgan, 384 U.S. 641,651 n.10 (1966)).

${ }^{146}$ See Cook, supra note 24, at 425-26 (noting that the language of the Full Faith and Credit Clause was intended by the Framers to give Congress the power to enforce "legislative acts as well as judgments and all other records and judicial proceedings" by way of "general laws"). 
acts, records, and proceedings. ${ }^{147}$ The DOMA does not look like the sort of legislation that was intended by the term "general Laws." 148

\section{Congress's Power to Legislate}

\section{a. The Withdrawal of Full Faith and Credit}

Before the DOMA's passage, there was limited debate on what the "give effect" provision authorized Congress to do. Most of this debate during consideration of the DOMA, however, centered on the DOMA's negative aspects, in that it represented the first congressional exemption from full faith and credit. Although there is no conclusive evidence that this distinction alone would be enough to invalidate the Act, many have expressed this view. ${ }^{149}$ Professor Laurence Tribe expressed the opinion that "Congress possesses no power under any provision of the Constitution to legislate any such categorical exemption from the Full Faith and Credit Clause of Article IV."

${ }^{147}$ Although there was considerable congressional debate about whether the Act exceeded Congress's power, very little was said about this particular aspect of the Clause. Scholars do not appear to have raised this particular issue either. Some commentators have assumed that Congress possesses the power to extend or withhold full faith and credit to specific acts, records, or judicial proceedings. These commentators have made these assumptions implicitly in their discussions, and have offered no support for these assumptions. See, e.g., Laycock, supra note 41, at 331 ("Congress can ... specify[] which state's law gets full effect in each class of cases, and concomitantly, that no other state's law gets any effect in that class of cases."); Sumner, supra note 24, at 239 (opining that "the members of the Constitutional Convention meant the clause to be self-executing, but subject to such exceptions, qualifications, and clarifications as Congress might enact into law" (emphasis added)).

${ }^{148}$ The Supreme Court has said, at least in dictum, that " $[t]$ he Full Faith and Credit Clause is not to be applied, accordion-like, to accommodate our personal predilections." Estin v. Estin, 334 U.S. 541, 545-46 (1948). In another case dealing with a Nevada divorce decree denied recognition by North Carolina, the Court noted that fine distinctions are difficult to make because of the "generality of the words of the full faith and credit clause." Williams, 317 U.S. at 301. This observation suggests that the Full Faith and Credit Clause does not lend itself to fine distinctions of any variety.

${ }^{149}$ Cf. sources cited supra note 11 (arguing that the purpose of the Full Faith and Credit Clause is to unify the states in a federal system and that this is a positive power only).

${ }_{150} 142$ CONG. REC. S5932 (daily ed. June 6, 1996) (letter of Professor Laurence H. Tribe). Professor Tribe based this conclusion on the fact that the power to exempt was not expressly delegated to Congress, and is therefore reserved to the states under the Tenth Amendment. See id. 
In response to Professor Tribe's argument that Congress may not detract from the otherwise ineluctable force of full faith and credit, the author of the congressional report asserted that "the power to prescribe does not distinguish between laws that would add to and those that would detract from the force of that obligation." ${ }^{51}$ The report's author also expressed the view that "while States are generally obligated to treat laws of other States as they would their ownCongress retains a discretionary power to carve out such exceptions as it deems appropriate. ${ }^{152}$ The Committee reached this conclusion by inferring that the language of the Full Faith and Credit Clause, which grants Congress the power to "prescribe the effect [of one state's] public acts, records, and proceedings" in other states, also confers upon Congress the power "to specify by statute how States are to treat laws from other States." ${ }^{153}$ This inference is unsound, however, because the Full Faith and Credit Clause permits Congress to "prescribe the Manner in which such Acts, Records, and Proceedings shall be proved, and the Effect thereof." Congress complete discretion to determine the effect of any given law or marriage, suggests that Congress will be administering a largely self-executing provision. ${ }^{155}$ Having built in a suggestion of congressional discretion in this initial inference, the author of the report then extrapolates to his conclusion that Congress can "carve out such exceptions as it deems appropriate. ${ }^{156}$

\section{b. Violation of the Generality Requirement}

Even if Congress does possess the power to withhold full faith and credit in certain situations, the DOMA still raises serious constitutional concerns. In particular, the narrowness of the exception carved in the DOMA is inconsistent with both the plain meaning and the purpose of the Full Faith and Credit Clause. The Clause grants Congress the power to pass "general Laws" regarding the effect of records, acts and proceedings. ${ }^{157}$ This provision might permit

\footnotetext{
${ }^{151}$ H.R. REP. NO. 104-664, at 26 n.71 (1996).

152 Id. at 25.

${ }^{353} I d$.

154 U.S. CONST. art. IV, $\$ 1$ (emphasis added).

${ }^{155}$ See Mills v. Duryee, 11 U.S. (7 Cranch) 481, 485 (1813) (observing that if the "judgments of the state courts ought to be considered prima facie evidence only, [the Full Faith and Credit Clause] would be utterly unimportant and illusory").

${ }^{156}$ H.R. REP. NO. 104-664, at 25.

157 U.S. CONST. art. IV, § 1 .
} 
Congress to except all marriages from the scope of the Full Faith and Credit Clause, but not specific marriages. ${ }^{158}$ One speaker, in arguing for passage of the DOMA, opined that "an exception is created if Congress chooses [to do so] by general law, as opposed to a specific law to a specific contract.", 159

In his testimony before the Senate Judiciary Committee, Professor Cass Sunstein expressed concern over the specificity of the DOMA. Professor Sunstein argued that one way to interpret Congress's power to legislate under the Full Faith and Credit Clause is to say that "Congress can single out those state acts and judgments of which it disapproves and give them no effect in other states. Does this power exist? It is certainly not clear. . . There is no historical evidence that this ... power was something that the framers thought to grant to Congress."

This view is not without problems. Among other things, Congress has legislated under the Full Faith and Credit Clause in narrow areas before. ${ }^{161}$ In all of this prior legislation, however, Congress extended the reach of the Full Faith and Credit Clause. For example, 28 U.S.C. $\S 1738 \mathrm{~A}$ requires states to give full faith and credit to child

${ }^{158}$ It is clear that Congress only intended to grant states the power to refuse recognition of extraterritorial same-sex marriages. A proposed amendment that would have applied section 2 to all marriages was rejected. See H.R. REP. No. 104664, at 20. Even assuming Congress could place all marriages outside of the scope of full faith and credit, such an enactment might implicate other constitutional concerns, such as Tenth Amendment issues.

159142 CONG. REC. H7274 (daily ed. July 11, 1996) (statement of Rep. Campbell). This reading of "general Laws" is too narrow. Congress may not pass a "specific law to a specific contract," $i d$., not because of the Full Faith and Credit Clause, but because of the constitutional prohibition that "[n]o Bill of Attainder . . . shall be passed." U.S. CONST. art. I, §9, cl. 3.

${ }^{160}$ Hearings on Marriage Act, supra note 141, at 46 (statement of Professor Cass R. Sunstein, University of Chicago). But see Laycock, supra note 41, at 331 ("Congress can designate the authoritative state law under the Effects Clause, specifying which state's law gets full effect in each class of cases, and concomitantly, that no other state's law gets any effect in that class of cases."). Even if this aspect of the DOMA is not, in itself, unconstitutional, the stated purpose behind the Act is inconsistent with the policies embodied in the Clause. This inconsistency, combined with the potentially impermissible line-drawing between opposite and same-sex couples, raises serious constitutional concerns.

${ }^{161}$ See sources cited supra note 56. That Congress has legislated in narrow areas before does not answer the constitutional concerns, however, as these recent enactments have not been challenged on constitutional grounds. The Supreme Court did address the Parental Kidnapping Prevention Act, 28 U.S.C. $\S 1738 \mathrm{~A}$, but merely interpreted the Act to provide a rule of enforcement and not a new cause of action. See Thompson v. Thompson, 484 U.S. 174 (1988). The Court did not address the constitutionality of the legislation as it was not at issue. See id. 
custody and support decrees entered in any other state. ${ }^{162}$ This legislation was designed to end the interstate confusion arising from states ignoring the valid decrees from other states and fashioning new decrees based on their own standards for the best interest of the child. ${ }^{163}$ More importantly, although this legislation targeted a narrow class of proceedings, it applied to all of the proceedings within that class. In contrast, the DOMA is the result of Congress sifting through the categories of acts, records, and judicial proceedings that might legitimize marriages, and winnowing out the narrow group-those legitimizing same-sex marriage.

Even if Congress does possess the power to except certain acts, records, and proceedings from the requirements of full faith and credit, the DOMA should still be invalidated in that it impermissibly interferes with the status of the states as independent sovereigns.

\section{B. The Effect of the DOMA on the Status of the States As Independent Sovereigns}

The second aspect of the DOMA that should warrant close judicial scrutiny is the effect this legislation will have on the sovereignty of the states. There was extended discussion during the legislative debates of the DOMA regarding the need to protect the states from having to recognize another state's same-sex marriages. ${ }^{164}$ Proponents of the DOMA advanced the argument that the legislation protects states from the intrusion of another state's public policy decisions. ${ }^{165}$ This concern, however, does not warrant congressional intervention. The same criticism was leveled at Nevada's permissive divorce laws in

${ }^{162} 28$ U.S.C. $\S 1738$ A (1994).

${ }^{16 s}$ See 4 WARDLE ET AL., supra note 54, § 40:07, at 46 (“[T] he courts' general avoidance of clarification on the related issues of full faith and credit ... in custody matters, caused confusion among various jurisdictions and allowed the state courts to feel free to disregard custody decisions of other state courts ...."); see also David Carl Minneman, Annotation, Recognition and Enforcement of Out-of-State Custody Decree Under $\$$ 13 of the Uniform Child Custody Jurisdiction Act (UCCJA) or the Parental Kidnapping Prevention Act (PKPA), 28 U.S.C. \$ 1738A(a), 40 A.L.R.5th 227 (1996) (detailing cases recognizing, enforcing, and refraining from modifying orders from other states). This congressional intervention, in the face of a national problem of custody decrees and parental kidnapping, see 4 WARDLE ET AL., supra note $54, \S 40: 07$, is consistent with the purposes underlying the Full Faith and Credit Clause. See discussion supra notes 25-37.

${ }_{164}$ See H.R. REP. 104-664, at 2 (stating that the purpose of the DOMA is to free states from the "constitutional implications" of one state's recognition of same-sex marriages).

${ }^{163}$ See 142 CONG. REC. S4870 (daily ed. May 8, 1996) (statement of Sen. Nickles) (referring to states' "fear that another State's laws may be imposed upon them"). 
the 1940s. The Supreme Court responded that "such an objection goes to the application of the full faith and credit clause to many situations. ... Such is part of the price of our federal system. ${ }^{1166}$

Closely related to this point is the fact that whenever a state asserts its sovereignty, it does so at the expense of another state. Thus, when Congress purports to strengthen the ability of the fortynine states to resist recognition of the valid same-sex marriages of Hawaii, this inevitably entails the sacrifice of Hawaii's status as a sovereign for purposes of regulating the marital status of some of its residents. One of the DOMA's sponsors insisted that the Act "does not intrude on the ability of the States to define marriage as they choose. ${ }^{\text {167 }}$ Yet, should Hawaii choose to define marriage to include same-sex couples, it will have no support for the recognition of those marriages in other states. This point was well made by one speaker, reading from a letter submitted by Professor Laurence Tribe:

Such purported authority to dismantle the national unifying shield of article IV's Full Faith and Credit Clause, far from protecting States' rights, would destroy one of the Constitution's core guarantees that the United States of America will remain a union of equal sovereigns, that no law, not even one favored by a great majority of the States, can ever reduce any single State's official acts, on any subject, to second-class status....

Under the traditional choice-of-law analysis, one state would not be permitted to apply its own laws to deny recognition of Hawaii's marriage unless it had both a significant interest in the marriage and a strong public policy against recognition of such a marriage. ${ }^{169}$ Yet, the DOMA purports to allow states with minimal or no interest in a marriage, or lacking a sufficient public policy against same-sex marriages, to refuse to recognize the marriage of another state. In a statement submitted to the Senate Judiciary Committee, Professor

${ }^{166}$ Williams v. North Carolina, 317 U.S. 287, 302 (1942). In contrast, a legislator referred to plans to have Hawaiian same-sex marriages recognized in other states as "profoundly undemocratic, and... surely an abuse of the Full Faith and Credit Clause." 142 CONG. REC. H7441 (daily ed. July 11, 1996) (statement of Rep. Canady).

${ }^{167} 142$ CONG. REC. S10,103 (daily ed. Sept. 10, 1996) (statement of Sen. Nickles).

${ }^{163}$ Id. at S10,104 (statement of Sen. Moseley-Braun) (quoting 142 CoNG. REC. S5932 (daily ed. June 6, 1996) (letter of Professor Laurence H. Tribe)); see also Hearings on Marriage Act, supra note 141, at 110 (statement of Professor Cass R. Sunstein, University of Chicago) (arguing that the Full Faith and Credit "clause's historic function is to ensure that states will treat one another as equals rather than as competitors").

\footnotetext{
${ }^{169}$ See supra Part II.B.
} 
Lynn Wardle, a conflict-of-laws scholar, asserted that a state must have "a significant contact" and "a significant public policy conflict" before the DOMA could authorize that state to refuse recognition of a Hawaii marriage. ${ }^{170}$ This characterization of the DOMA suggests that the Act only replicates the current conflict-of-laws choices available to states, yet such a characterization is misleading. As Professor Wardle conceded, full faith and credit "might arguably preclude nonrecognition" of a same-sex marriage in the absence of such contacts and policy conflicts. ${ }^{171}$ However, the DOMA requires neither a significant contact nor a significant policy conflict before nonrecognition.

The sovereignty of the states is also threatened by the encroachment of the federal government in this area. One of the drafters of the Full Faith and Credit Clause expressed concern that the Clause would allow the federal government to usurp state powers. ${ }^{172}$ Echoing this concern, many opponents of the DOMA cautioned that the Act's interpretation of the Full Faith and Credit Clause would open the way for Congress to intrude into any area that it chose: "If Congress invokes the full faith and credit clause to deny effect to unpopular State court judgments, why will it stop at gay marriages?"173 This possible aggrandizement of federal power, at the expense of the states, should warrant close scrutiny.

\section{CONCLUSION}

As the preceding discussion has argued, the DOMA is constitutionally suspect. It is remarkable in that it represents the first attempt by Congress to withhold the demands of full faith and credit from a class of records, acts, and judicial proceedings. Although this anomaly of the DOMA would most likely be insufficient to invalidate the legislation, its novelty should at least arouse the suspicion of the

${ }^{170}$ See Wardle, supra note 144, at 128.

171 See id.

172 See Cook, supra note 24, at 425 (noting statements by Mr. Randolph). One opponent of the DOMA argued that "[t]he Constitution gives Congress no power to add or subtract from the full faith and credit clause. The States that ratified the Constitution would never have granted such sweeping authority to Congress ...." 142 CONG. REC. S10,102 (daily ed. Sept. 10, 1996) (statement of Sen. Kennedy).

173142 Cong. REC. S10,102 (daily ed. Sept. 10, 1996) (statement of Sen. Kennedy). This concern was frequently expressed during the debates. See, e.g., id. at S10,118 (statement of Sen. Feinstein) (quoting Professor Sunstein's testimony before the Senate Judiciary Committee in asserting that '[u]nder the proponents' interpretation, Congress could simply say that any law that Congress dislikes is of no effect in other States"). 
Supreme Court. The aspect of the DOMA, however, that will require the closest scrutiny by the Court is the specificity with which the affected class was drawn. Rather than withholding full faith and credit from all marriages, or extending full faith and credit to an entire class of judicial proceedings, ${ }^{174}$ the DOMA singles out same-sex marriages for exclusion from the exigencies of full faith and credit. This Comment takes the position that the Full Faith and Credit Clause does not grant Congress such discriminating powers. Rather, Congress's power to legislate under this Clause is limited to enacting "general Laws," not specific laws targeting records, acts, and judicial proceedings with which it disagrees.

Even if Congress does possess the power under the Full Faith and Credit Clause to legislate in this selective manner, the application of the DOMA in certain circumstances would still violate full faith and credit requirements. With passage of the DOMA, Congress purports to grant states the absolute power to deny recognition of another state's same-sex marriage, or any incident thereof, regardless of the invalidating state's interest in the marriage and without reference to that state's public policies. Although some proponents of the DOMA argued that it bolstered the existing ability of the states to decide matters of public policy, this legislation goes too far. It must be recalled that one state asserts its sovereignty only at the expense of another state's. Thus, although the DOMA appears to expand the sovereignty of a state which refuses to recognize a Hawaiian same-sex marriage, it only does so at the cost of Hawaii's sovereignty. The DOMA strips Hawaii of most of its power and interest in having its marriages recognized in other states.

The system of independent sovereigns embodied in our government necessarily involves some conflict; "[s] uch is ... the price of our federal system." ${ }^{175}$ The possibility of Hawaii recognizing same-sex marriages is merely one such conflict. Unless and until the states cannot resolve a conflict among themselves, there is neither need, nor constitutional support, for congressional intervention. "[E]very experiment that bubbles up from one of the 50 different state 'laboratories of democracy' [need not be] a national issue in need of

${ }^{174}$ See, e.g., 28 U.S.C. $\$ 1738$ A (1994) (requiring states to give full faith and credit to the child support and custody determinations of other states).

${ }^{175}$ Williams v. North Carolina, 317 U.S. 287, 302 (1942). 
a single national solution."176 Regardless of the eventual fate of the DOMA, however, it remains a crucial piece of legislation for full faith and credit jurisprudence because it will provide the Court with a much needed opportunity to examine and determine the precise meaning of "general Laws" and the parameters of Congress's power to legislate under the Full Faith and Credit Clause.

${ }^{176}$ James P. Pinkerton, The Principle of States Rights: Conservatives Should Embrace Gay Marriage Ruling, RECORD (Bergen, N.J.), Dec. 10, 1996, at L13, available in 1996 WL 6122267. 
